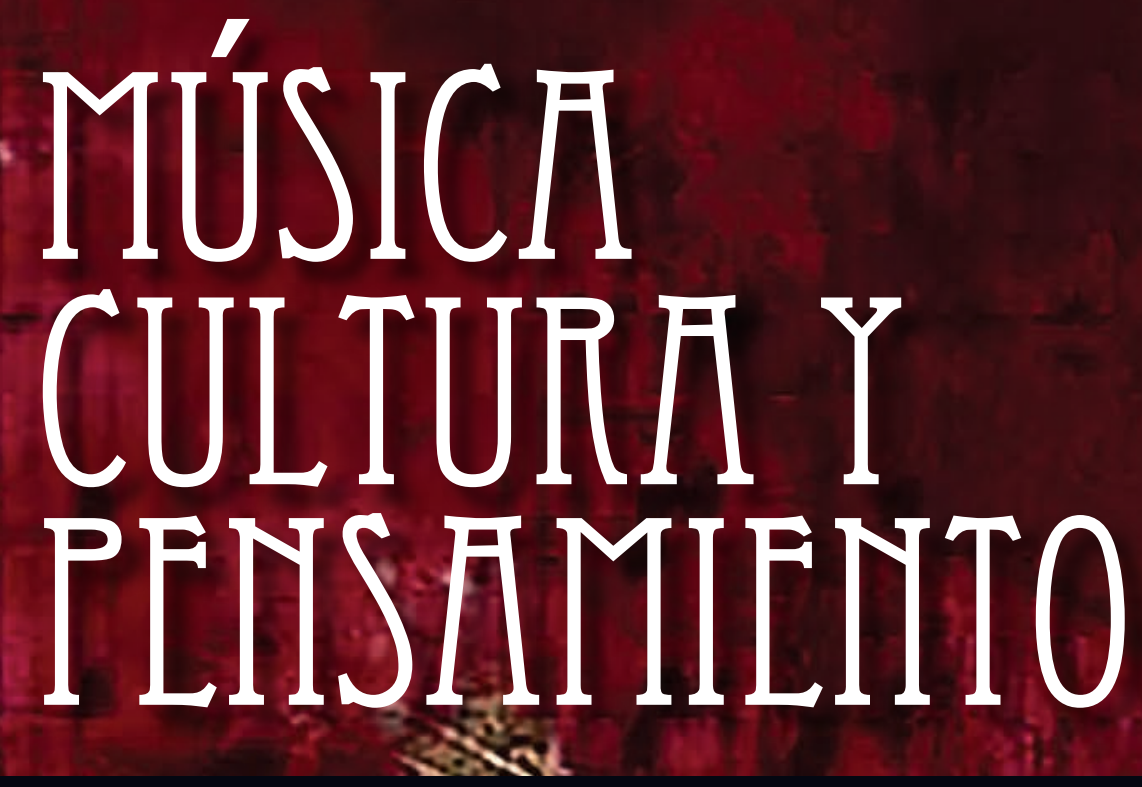

Revista de investigación de la Facultad de Educación y Artes del Conservatorio del Tolima

VOL. VI N.॰ 6 - Noviembre 2017

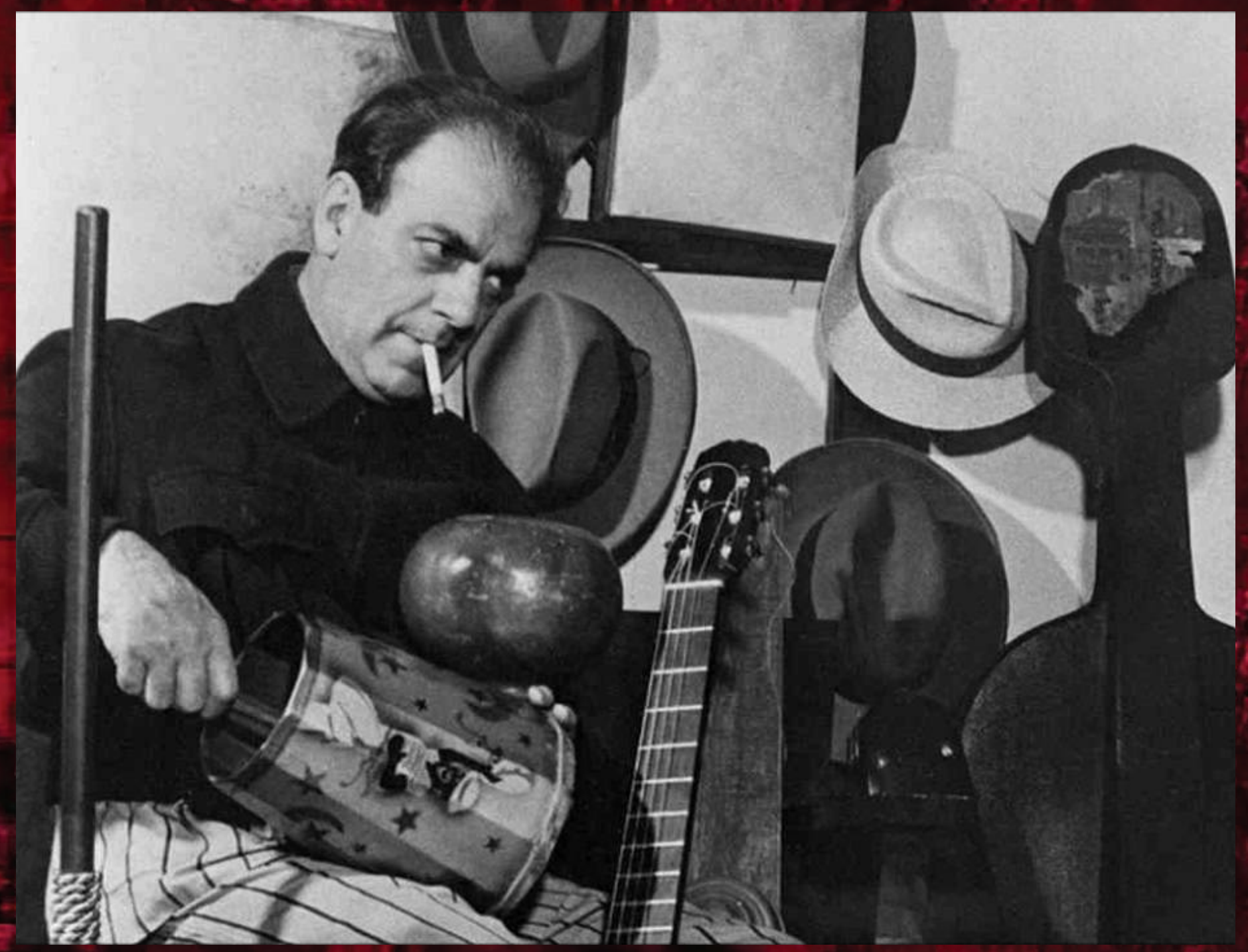




\section{Índices revista (números 1 a 5)}

\section{9}

Música, Cultura y Pensamiento $N^{0} 1$

\section{Artículos}

Gil, F. (2009). Congresos Nacionales de la Música, 1936-1937. Música, Cultura y Pensamiento, 1(1), 13-34. Ibagué: Conservatorio del Tolima.

\section{Resumen}

Fueron fundamentales para la cultura musical, y en particular para la educación y la práctica musical en Colombia, las acciones desarrolladas por la Dirección Nacional de Bellas Artes (DNBA) del Ministerio de Educación Nacional entre los años 1935 y 1937. Los Congresos Nacionales de la Música, eventos coordinados por la DNBA, trataron de democratizar la participación de los músicos de diferentes regiones en la construcción de la música nacional, con ideales liberales, buscando un mayor acceso de población a la educación especializada en música y retomando la bandera de la divulgación y apropiación del conocimiento científico en la formulación de problemas en torno a la pedagogía musical y el arte. En ellos se validaron muchos de los esfuerzos y políticas que desarrolló la DNBA con-

\section{Resúmenes 2009}

gregando intelectuales y músicos en torno al fortalecimiento de la música nacional.

Palabras clave: Congresos Nacionales de la Música en Colombia, educación y la práctica musical en Colombia, construcción de la música nacional, problemas en torno a la pedagogía musical y el arte, pensamiento musical colombiano.

Title: National Music Congresses, 1936-1937.

\begin{abstract}
The actions undertaken by the National Direction of Fine Arts (DNBA) from the National Education Department between 1935 and 1937 were fundamental for the music culture and, in particular, the education and practice of music in Colombia. The National Music Congresses, coordinated by the DNBA, tried to democratize the participation of the musicians from different regions in order to construct the national music, with liberal ideals wanting to facilitate the general population's access to specialized education in music, while recapturing the flag of the publication and the appropriation of scientific knowledge in the formulation of problems concerning music and art pedagogies. This validated many of the efforts and policies developed
\end{abstract}


by the DNBA which congregated intellectuals and musicians in order to strengthen the national music.

Keywords: National Music Congresses in Colombia, education and music practice in Colombia, construction of the national music, problems concerning music and art pedagogies, Colombian musical thought.

Beltrán Agudelo, L. A., Guarín Ramírez, N., Carrión Tovar, M. Á. y Galindo Palma, H. (2009). Línea de investigación en Historia y Patrimonio del Conservatorio del Tolima: aproximacion es teórico-metodológicas. Música, Cultura y Pensamiento, 1(1), 35-47. Ibagué: Conservatorio del Tolima.

\section{Resumen}

El Grupo de Investigación Historia y Patrimonio del Conservatorio del Tolima está constituido por directivos y docentes institucionales. Con la participación de los estudiantes de la Licenciatura en Música, por medio de sus trabajos de grado, este grupo lidera proyectos de investigación institucionales en la línea que aquí se presenta. Como punto de partida, la línea de investigación define conceptos e identifica de manera apropiada los aspectos que le permiten lograr claridad en los distintos momentos del trabajo investigativo propuesto en el contexto propio, con el fin de tener un conocimiento sólido de la teoría que fundamenta y guía la reconstrucción de la historia cultural, educativa y artística del Conservatorio del Tolima.

Palabras clave: investigación, música, historia, memoria, relato, documento.

Title: Investigation into History and Heritage of the Tolima Conservatory: theoretical and methodological approaches.

\begin{abstract}
The research Group "History and Patrimony of the Tolima Conservatory" is made up of managers and institutional teachers. With the participation of the students from the Bachelor of Music degree and their graduation theses, this group leads institutional research projects. As a starting point, the investigation defines concepts and identifies the aspects that provide clarity in the different moments of the proposed research in an appropriate context, in order to have a solid knowledge of the theory that bases and guides the reconstruction of the cultural, educational and artistic history of the Tolima Conservatory.
\end{abstract}

Keywords: investigation, music, history, memory, history, document.

Londoño Fernández, M. E. (2009). Memoria colectiva y músicas locales en una perspectiva de desarrollo humano. Música, Cultura y Pensamiento, 1(1), 35-47. Ibagué: Conservatorio del Tolima.

\section{Resumen}

El texto dimensiona la memoria colectiva y la sitúa en el centro de las dinámicas sociales y culturales. Destaca el papel privilegiado del arte, y en particular el de la música como memoria, como elemento de comunicación y de cohesión social. Aborda el concepto de desarrollo en países como Colombia, atravesados por la multiculturalidad y la inequidad; sustenta la importancia de cuidar, valorizar y re-crear las músicas locales, rurales y urbanas asumidas como memoria colectiva, y muestra diversas posibilidades de aprovechamiento de este patrimonio cultural singular y propio, que ofrece alternativas múltiples al desarrollo humano, individual y comunitario. Con- 
voca a una recuperación crítica de la memoria e invita al fortalecimiento de redes ciudadanas que asuman, conscientemente, las tareas necesarias para lograrlo.

Palabras clave: memoria cultural, patrimonio cultural, multiculturalidad e inequidad en Colombia, músicas locales, rurales y urbanas, arte y memoria, música y desarrollo humano.

Title: Collective memory and local music in a human development perspective.

\begin{abstract}
The text gives dimension to the collective memory and places it in the center of the social and cultural dynamics. It emphasizes the privileged role of art, and in particular, that of music as a memory, as an element of communication, and social cohesion. It tackles the concept of development in countries like Colombia, affected by multiculturalism and inequity; it sustains the importance of taking care of, valuing and recreating the local, rural and urban music acknowledged as collective memory, and shows diverse possibilities of using this singular and independent cultural heritage, which offers multiple alternatives to the human, individual and community development. It summons a critical recovery of the memory and encourages the strengthening of civil networks that assume, consciously, the necessary tasks to achieve it.
\end{abstract}

Keywords: cultural memory, cultural heritage, multiculturalism and inequity in Colombia, local, rural and urban music, art and memory, music and human development.

Beltrán Agudelo, L. A., Millán, Á. J., Rivas Quijano, D. E., Espinosa, H. (2009). Amina Melendro de Pulecio: La legendaria madrina de la música. "Un compromiso con la his- toria”. Música, Cultura y Pensamiento, 1(1), 65-74. Ibagué: Conservatorio del Tolima.

\section{Resumen}

Este artículo describe la historia de la señora Amina Melendro de Pulecio, una de las principales protagonistas de la historia del Conservatorio del Tolima, construida con quienes testimoniaron desde sus recuerdos las experiencias y datos que tenían sobre su relación familiar, de amistad o de trabajo con la protagonista, información que, apoyada en la constatación documental, hizo posible esta versión de su historia de vida, denominada: "Amina Melendro de Pulecio: La legendaria madrina de la música". La investigación inició desde el mismo momento en que apareció el primer Melendro en Colombia, tratando de reconstruir de una manera fidedigna la infancia y la juventud de la señora Amina, y tomando luego su vida laboral en el Conservatorio del Tolima, desde el año 1927 hasta 1999. La información fue sintetizada en los logros más significativos, reconociendo que fue una vida muy productiva y trascendente para el Conservatorio del Tolima, para Ibagué y Colombia.

Palabras clave: Amina Melendro de Pulecio, protagonista de la historia del Conservatorio del Tolima, patrimonio musical colombiano, historia de vida, estudio de género.

Title: Amina Melendro de Pulecio: The legendary godmother of music "A commitment to history".

\section{Abstract}

This article describes the history of Mrs. Amina Melendro de Pulecio, one of the principal protagonists in the history of the Tolima Conservatory. The history was reconstructed with the help of different memories, experiences, and information 
given by family, friends and colleagues. This information has been confirmed by several documents and made the current version of her life's storycalled: "Amina Melendro de Pulecio: A Legendary Godmother of Music. The research begins when the Melendro family arrived in Colombia, and tries to correctly reconstruct Mrs. Amina's childhood and youth, and then moves on to talk about her working life in the Tolima Conservatory, from 1927 to 1999.

Keywords: Amina Melendro de Pulecio, protagonist of the history of the Conservatory of the Tolima, Colombian musical patrimony, life history, study of genre.

Beltrán Agudelo, L. A., Güisa, M. A., Bautista, S. I. y Luna, M. A. (2009). Vicente Sanchis Sanz: Leyenda viva de una época dorada. Música, Cultura y Pensamiento, 1(1), 75-89. Ibagué: Conservatorio del Tolima.

\section{Resumen}

La llegada de un emigrante español en los años sesenta a Colombia, era rara, casi única, pues no existían motivos para venir de lugares tan lejanos. Sin embargo, un músico de Valencia, con anhelos de conocer y sobre todo de librarse de su medio político, decidió viajar a Ibagué para enseñar música. Lo que encontró Vicente Sanchis Sans en Ibagué y en el Conservatorio, fue algo maravilloso, era como un terreno abonado donde él podía depositar muchas semillas de futuro. Se asombró del talento y el interés de los niños y los jóvenes del Conservatorio del Tolima, por la música. Así que con toda la energía que poseía a sus veinticinco años, supo crear un ambiente propicio para enseñar todo lo que sabía y además de organizar la orquesta, los coros y los grupos de cámara, donde encausó la capacidad y el interés de los estudiantes, generó una verdadera época dorada de la música en Ibagué.

Palabras clave: Vicente Sanchis, músico, director español en Colombia, historia de vida, historia del Conservatorio del Tolima.

Title: Vicente Sanchis Sanz: Living legend of a golden age.

\section{Abstract}

The arrival One Spanish Inmigrant to Colombia in the 60s was rare and almost unique given that in those days, there weren't many reasons to travel from such distant places. Nevertheless, a musician from Valencia, wanting to discover and escape the Spanish political system, decided to travel to Ibagué to teach music. What Vicente Sanchis Sans found in Ibagué and in the Conservatory, was something wonderful, it was like a solvent area where he could deposit many future seeds. He was astonished at the talent and the interest in music that the children and the young people of the Tolima Conservatory displayed. So, at twenty-five, using all his energy, he created a propitious environment where he taught everything he knew and organized the band, the choirs and chamber music groups. He guided his students' potential and interests, all the while generating a real golden age of music in Ibagué.

Keywords: Vicente Sanchis, musician, the Spanish director in Colombia, life history, history of the Tolima Conservatory.

Hernández Guayara, A. y Varón, A. P. (2009). Álvaro Ramírez Sierra: Crónica de un compositor vanguardista colombiano. Música, Cultura y Pensamiento, 1(1), 91-97. Ibagué: Conservatorio del Tolima. 


\section{Resumen}

La obra musical del compositor Álvaro Ramírez Sierra (1932-1991) forma parte de un proyecto de investigación liderado por el guitarrista Gustavo Niño Castro. Este proyecto inició en el año 2006 en el Conservatorio del Tolima, con la participación de docentes y estudiantes de la Facultad de Educación y Artes de la misma institución. En la actualidad (2009), el proyecto tiene como primeros productos la edición de 23 manuscritos del compositor y una compilación de 108 de sus obras. Producto de dicha investigación, este artículo busca presentar a la comunidad académica un perfil biográfico de este desconocido personaje; de su vida musical, sus logros, su pensamiento y del legado musical vanguardista para su época, que dejó para las nuevas generaciones.

Palabras clave: Álvaro Ramírez Sierra, música colombiana del siglo xx, compositor vanguardista - historia de vida, catalogación musical.

\section{Abstract}

The work of the composer, Álvaro Ramírez Sierra (1932 - 1991), is part of a research project led by the guitarist Gustavo Niño Castro. The project began in 2006 in the Tolima Conservatory, with the participation of a group of teachers and students from the institution's faculty of Education and Arts. At present (2009), the project includes the edition of 23 of the composer's manuscripts and a compilation of 108 of his works. This article aims to provide the academic community an insight into the biographic profile of this unknown character, including his musical life, his achievements, his way of thinking, as well as the musical legacy he left for the future generations.

Keywords: Álvaro Ramírez Sierra, Colombian musician of the XXth century, avant-garde composer, life history, musical cataloging.
Galindo Palma, H. (2009). Instrumentarium: Las culturas tradicionales vistas desde el patrimonio instrumental musical. Música, Cultura y Pensamiento, 1(1), 99-111. Ibagué: Conservatorio del Tolima.

\section{Resumen}

Los instrumentos musicales son las evidencias más tangibles de identidad sonora colectiva que puedan hallarse en cualquier cultura, sea como referencia de su pasado, presente ofuturo, ydesdesumorfologíay funcionalidad, revelan elementos cohesionadores de la música de una sociedad particular con respecto a otras. La organología, como rama especializada de la musicología sistemática y de la etnomusicología, se ha consolidado en una de las herramientas metodológicas más pertinentes del siglo xxı para estudiar las culturas musicales tradicionales, en busca de una mejor comprensión de una praxis colectiva desde sus instrumentos musicales. El coleccionismo de instrumentos musicales de diversas culturas para su estudio, actividad que ha dado lugar a la creación de los museos especializados en música en todo el mundo, se vislumbra para el siglo xxı como uno de los más importantes escenarios de preservación, estudio y difusión de la organología musical de todas las culturas en las sociedades modernas. El presente artículo reflexiona sobre las perspectivas y sus horizontes de la organología musical en un contexto histórico global y su relación con el desarrollo de la etnomusicología en Colombia.

Palabras clave: etnomusicología y organología, patrimonio instrumental musical colombiano, culturas musicales tradicionales, museos organológicos musicales.

Title: Instrumentarium: Traditional cultures seen from the instrumental musical heritage. 


\begin{abstract}
Musical instruments are the most tangible evidence of the collective sonorous identity of any culture. They are like a reference of a culture's past, present, or future, and their morphology and functionality reveal the cohesion elements of music in a particular society in respect to other cultures. The organology, as a specialized branch of systematical musicology and ethnomusicology, has been consolidated as one of the most pertinent methodological tools of the Twenty First Century to study traditional musical cultures, looking for a better understanding of a collective praxis from the musical instrument view point. Collecting musical instruments from diverse cultures for their study, is an activity that has given place to the creation of specialized music museums all over the world. They are foreseen as the most important sceneries for preservation, study and diffusion of the musical organology of the Twenty First century in all cultures of modern societies. The present article reflects on the perspectives and horizons of the musical organology in a global historical context, and its relation with the development of ethnomusicology in Colombia.
\end{abstract}

Keywords: ethnomusicology and musical organology, Colombian musical instrumental patrimony, traditional musical cultures, music museums.

Sánchez Suárez, S. (2009). Reflexión histórica de las formas de la escritura musical del bambuco, entre el colonialismo y la República en Colombia. Música, Cultura y Pensamiento, 1(1), 115-130. Ibagué: Conservatorio del Tolima.

\section{Resumen}

Durante los últimos dos siglos de historia musical en Colombia, académicos, intérpretes, directores de ensambles, musicó- logos, etnomusicólogos, arreglistas, compositores y todos aquellos que hacen parte del oficio, se han enfrentado al dilema de "cómo escribir el bambuco" en una partitura. Este problema ha creado discursos y polémicas alrededor de este tema, que sin dejar nada productivo en términos académicos, ha logrado polarizar dos grupos de acérrimos creyentes. Los que escriben el bambuco a 3/4 y los que defienden la posición de su escritura a 6/8, como la más práctica. Para entender este problema, se debe considerar todo el contexto histórico que encierra este debate musical y sus diferentes variables sociales, desde los procesos de colonización hasta los de instauración del concepto de Patria dentro de la creación de la nueva República colombiana. Este artículo se desarrolla en dos partes. La primera es una síntesis y reflexión socio-histórica de los procesos evolutivos de la creación del bambuco, su origen y antecedentes, las primeras consecuencias de su instauración como ritmo nacional además de las referencias históricas respecto a su escritura durante el siglo xx. En la segunda parte se hace un análisis y comparación de las más importantes formas de la escritura, y se presenta una reflexión alrededor de la manera adecuada de llevarla a la partitura y su posible influencia en la interpretación.

Palabras clave: análisis, epistemología, musicología, música colombiana, bambuco, interpretación.

Title: Historical reflection of the forms of bambuco musical writing, between colonialism and the Republic in Colombia.

\section{Abstract}

During the last two centuries of musical history in Colombia, academics, interpreters, assemble directors, musicologists, ethno musicologists, music arrangers, composers and other related professions, have 
faced the dilemma of "how to write Bambuco" in score form. This problem has led to speeches and polemics about the topic that despite not being productive in academic terms, has managed to polarize two groups of staunch believers: those who write Bambuco in 3/4 and those who defend the position of writing it in $6 / 8$. To understand this problem, it is necessary to consider the whole historical context of this musical debate, as well as its different social variables from the processes of colonization to the establishment of the concept of Homeland in the creation of the new Colombian Republic. This article includes two parts. The first one is a synthesis and historical reflection of the evolutionary processes of the creation of Bambuco, its origins, precedents, the first consequences of its establishment as a "National rhythm", and historical references with regard to its writing during the Twentieth century. The second part is an analysis and comparison of the most important forms of its writing, bringing up the debate about the "suitable" way of writing it in musical score form and its possible influence in its interpretation.

Keywords: analysis, epistemology, musicology, Colombian music, bambuco, interpretation.

Ramírez Méndez, A. C. (2009). Suite Op. 18: Una aproximación a los ritmos andinos desde la armonía moderna. Música, Cultura y Pensamiento, 1(1), 131-138. Ibagué: Conservatorio del Tolima.

\section{Resumen}

Hacia 1864, Johannes Brahms compone su trío Op. 40 para corno, violín y piano. De esta obra se alegó que era inusual, por estar originalmente compuesta para waldhorn o corno de caza. Con todo, la historia ha demostrado que es un refinado acierto para la música de cámara, a pesar de ser un formato atípico, poco explorado por los compositores. Entrando al siglo $\mathrm{xxI}$, incluso en el siglo pasado, son pocos los compositores que se concentran en este conjunto. Esa preocupación por el pobre repertorio, ha impulsado a algunos compositores jóvenes en Colombia a centrarse en la producción de nueva música para grupos instrumentales no tan convencionales como el citado en este texto. De allí nace la idea de impulsar la interpretación de música colombiana desde este trío instrumental, a partir de la obra Suite Op. 18 que se describe en el presente artículo.

Palabras clave: suite para trío corno, violín y piano, jóvenes compositores colombianos, análisis musical, trío, armonía del siglo xx, danzas colombianas, música de cámara.

Title: Suite Op. 18: An approach to Andean rhythms from modern harmony.

\section{Abstract}

By 1864, Johannes Brahms composed his trio Op. 40 for the horn, violin and piano. It was alleged that this work was unusual because it was originally composed for the Wald horn or hunter horn. In spite of this, history has demonstrated that it is a refined success for the chamber music, despite being an atypical format and hardly explored by composers. In the Twenty-first century and the last century, there aren't many composers who concentrate on this musical format. This concern for the poor repertoire has impelled some young composers in Colombia to focus the production of new musical pieces for instrumental groups on not so conventional music types such as the one mentioned in this text. This has given rise to encouraging the interpre- 
MÚSICA, CULTURA Y PENSAMIENTO • NOVIEMBRE 2017

VOL. VI(6) | 6-45

tation of Colombian music such as the creation of the Suite Op. 18 which is described in the this article.

Keywords: suite for trio horn, violin and piano, young Colombian composers, musical Trio, harmony of the XXth century, Colombian Dances, chamber music.

\section{Separata}

Alarcón, J. G. (2009). Fantasía sobre Juan el Bautista - para órgano. Música, Cultura y Pensamiento, 1(1), 1-20 [Separata]. Ibagué: Conservatorio del Tolima. 


\section{0}

Música, Cultura y Pensamiento N. ${ }^{\circ} 2$

\section{Artículos}

Quevedo Urrea, J. (2010). Memorias documentales del sonido inédito: algunos aspectos técnicos documentales y jurídicos. Música, Cultura y Pensamiento, 2(2), 17-30. Ibagué: Conservatorio del Tolima.

\section{Resumen}

La memoria inédita sonora está representada por todo conocimiento que no ha sido difundido ni producido por la industria editorial, fonográfica o audiovisual haciendo parte de prácticas culturales específicas generalmente de tradición oral. El artículo expone, mediante ejemplos del patrimonio sonoro inédito del Centro de Documentación Musical, los diferentes procesos y criterios de identificación de materiales sonoros disponibles para realizar catalogaciones y bases de datos. Plantea criterios para el levantamiento de información técnica con un interés investigativo basado en dichos materiales, y hace énfasis en la necesidad de incorporar la tecnología para la actualización y análisis de archivos sonoros, tarea en la que viene trabajando el Centro de Documentación Musical. En la última parte se exponen algunas perspectivas de orden jurídico y técnico que deben observarse como políticas de ética, en consideración al debido proceso de protección de los derechos de autor sobre el material documental sonoro que es registrado o dado en depósito en colecciones de uso público.

Palabras clave: memoria inédita, documento sonoro, condiciones técnicas y jurídicas de registro y uso, bases de datos y análisis de documentos sonoros, Centro de Documentación Musical.

Title: Documentary memories of the unpublished sounds: some technical documentary aspects and legal aspects.

\section{Abstract}

Unpublished sound memory is represented by all knowledge that has not been released or produced by the publishing, phonographic and/or audio industry, and is part of specific cultural practices, generally oral tradition. This article describes, with examples of unpublished sound heritage from the Musical Documentation Centre, the different processes and criteria for the identification of audio material available for catalogues and databases. It proposes criteria to build up technical information with research interests based on those materials, and emphasizes the need to incorporate technology for updating and analyzing sound files, a task that has been carried out by the Musical Documentation Center. In the last part of the text, some legal and technical perspectives have been given and should be seen as ethical policies in regard to the due copyright process on sound documentary material that is recorded or in trust collections for public use.

Keywords: unpublished report, documentary sound, technical and legal conditions of registration and use, data-bases and analysis of sound recordings, Musical Documentation Center.

Sossa Santos, J. (2010). Pedagogía del acontecimiento: una experiencia de educación no formal para las músicas regionales. Música, Cultura y Pensamiento, 2(2), 31-44. Ibagué: Conservatorio del Tolima. 


\section{Resumen}

Con la presente reflexión se propone hacer un trazado de orden conceptual y de modos de intervención pedagógica que caracterizan nuevas maneras de hacer pedagógico; se señalan nuevas posibilidades de pensar e intervenir las músicas regionales que se consideran parte de una categoría más englobante: las denominadas Músicas Caribeiberoamericanas. Se habla de los enfoques convencionales de la educación musical, con sus rasgos de centralidad, jerarquías y linealidad y se proponen aproximaciones de lo que se denomina paradigma estético. Desde conceptos como rizoma y pedagogía del acontecimiento se muestran maneras inéditas de abordar la formación musical desde la perspectiva de la educación para el trabajo y el desarrollo humano, en contraste con las miradas canónicas propias de la educación formal de corte académico.

Palabras clave: rizoma, acontecimiento, músicas CIAM (Caribeiberoamericanas), mediación, literalidad-oralidad.

Title: Pedagogy of the event: a non-formal educational experience for regional music.

\section{Abstract}

With this reflection the construction of a conceptual and pedagogical path with intervention modes that characterize new forms of pedagogical work is proposed. It also identifies new opportunities to think and act in regional music that are considered part of a more encompassing category: the so-called Caribeiberoamericana Music. It talks about conventional approaches to musical education, with its qualities of centrality, hierarchy and linearity and proposed approaches called aesthetic paradigm. From concepts such as rhizome and pedagogy from the event, ways to deal with unprecedented musical training from the perspective of education for work and human development will be shown, in contrast to the canonical looks of formal academic education.

Keywords: rhizome, event, music CIAM (Caribeiberoamericanas), mediation, literal-oral.

\begin{abstract}
Alarcón Carreño, J. G. (2010). Reflexión histórica de la dirección sinfónica en Colombia: Directores destacados. Música, Cultura y Pensamiento, 2(2), 45-53. Ibagué: Conservatorio del Tolima.
\end{abstract}

\section{Resumen}

Poco o nada se ha escrito sobre la dirección sinfónica en Colombia y sus directores a lo largo de la historia, y el papel social-cultural de esta profesión en el campo laboral. Durante las últimas décadas, la música en Latinoamérica ha sido conductora de procesos de transformación social, como el movimiento orquestal en Venezuela y la red de orquestas de Medellín, o la Fundación Batuta, siendo el medio por el cual muchos niños y jóvenes tienen la oportunidad de progresar y salir adelante. El presente artículo hace una síntesis sobre los orígenes de la dirección en Colombia. Se habla sobre el papel actual del director en sus campos de acción, los procesos de formación y se hace una reflexión final sobre su proyección.

Palabras clave: compañías de ópera, directores en Colombia a finales del siglo xix y comienzos del xx, campo laboral de la dirección en Colombia, formación de los directores, reflexión histórica.

Title: Historical Reflection of the Symphonic Direction in Colombia: Featured Directors.

\section{Abstract}

Little or nothing has been written about the symphonic direction in Colombia and 
its directors throughout history, and the social-cultural roleofthis professionin thelabor field. During the last decades, music in Latin America has been conducting social transformation processes, such as the orchestral movement in Venezuela, and the network of orchestras in Medellín, or the Batuta Foundation in Colombia, which have offered many children the opportunity to progress and move forward. In Colombia and Latin America, the director leads the formation processes for orchestras, choirs and bands; his labor goes beyond simply moving the baton, profiling him as a manager and leader who teaches and transforms society by means of his musical labor. In this article the history of the first directors who came to Colombia, as well as the most prominent ones, is presented. It talks about the current role of the director in Colombia, his field of action and training process, as well as offering a final reflection on his projection in Colombia.

Keywords: opera company, directors in Colombia in the late nineteenth and early twentieth centuries, director's labor field in Colombia, director's training, historical reflection.

Leal Castro, C. D. (2010). La autoevaluación en el docente universitario: una actividad indispensable para la cualificación de los procesos educativos. Música, Cultura y Pensamiento, 2(2), 55-60. Ibagué: Conservatorio del Tolima.

\section{Resumen}

Para nadie es un secreto que la evaluación educativa hoy en día es objeto de una amplia gama de reflexiones y debates en el contexto nacional que reivindican su trascendencia como una actividad necesaria. Esto obedece en gran parte al imaginario predominante en el mundo educativo según el cual "aquello que no se evalúa, no se mejora”. Sin embargo, esta presunción parece tener relativa validez, pues no se trata de evaluar "sin ton ni son", como lo afirma Miguel Ángel Santos Guerra, o de evaluar atendiendo de forma sumisa y unívoca a los intereses externos del mercado del trabajo, del poder, del dinero, de la injusticia y de la desigualdad (Santos Guerra, 2001). Se trata de evaluar con base en criterios éticos racionales que le permitan al docente apelar a su autonomía y al ejercicio reflexivo como condiciones sine qua non para alcanzar una calidad cimentada en un aspecto que le debe ser inherente al docente en el mundo actual y que desde la filosofía platónica y algunos pensadores modernos como Descartes, Spinoza o Kant ya se dilucidaba como piedra angular para la formación del hombre: la necesidad de pensar, de aprender a pensar por sí mismo.

Palabras clave: evaluación, autoevaluación, autonomía, calidad, educación.

Title: Self-evaluation in the university teacher: an indispensable activity for the qualification of the educational processes.

\section{Abstract}

It is no secret that educational assessment is currently subject to a wide range of discussions and debates in a national context in favor of its importance as a necessary activity. This is largely due to the dominant imagery in the educational world, according to which "what is not evaluated is not improved." However, this assumption seems to be relatively valid, as it is not only about assessing "without rhyme or reason", as stated by Miguel Angel Santos Guerra, neither is it about assessing in a submissively and unambiguous way the external interests of the labor market, power, money, in- 
justice and inequality (Santos Guerra, 2001). Instead, it is about assessing based on rational and ethical criteria that allow the teacher to use their autonomy and reflective practice as sine qua non to achieve a quality rooted in an aspect that should be inherent to the teacher in the world today, and from the view point of platonic philosophy and modern thinkers such as Descartes, Spinoza or Kant who have elucidated as a cornerstone for the formation of man: the need to think, to learn to think for himself.

Keywords: evaluation, self-assessment, autonomy, quality, education.

Cárdenas Soler, R. N. (2010). Neurología y cognición musical. Música, Cultura y Pensamiento, 2(2), 61-69. Ibagué: Conservatorio del Tolima.

\section{Resumen}

El presente texto se fundamenta en tres artículos: "The Neuroscientific Basis of Music: Applications to the Development of Talent and Education" de William Bart y Michael Athernon, "Swinging in the Brain: Shared Neural Substrates for Behaviors Related to Sequencing and Music" de Janata y Grafton y "Towards a Neural Basis of Music Perception" de Koelsch y Siebel. Adicionalmente, su desarrollo se encuentra matizado por otros autores e investigadores que relacionan sus postulados con los temas tratados por los tres primeros artículos mencionados. Vale la pena resaltar la importancia del trabajo interdisciplinario en los hallazgos científicos que se pueden lograr en cada campo del saber, constituyéndose en un significativo aporte para el fortalecimiento e impulso de la ciencia. En este caso, estos estudios tendrían una importante implicación pedagógica para la educación musical, de manera particular, pero también para la educación general, revalidando la apreciación y la importancia de los procesos musicales en la escuela.

Palabras clave: cerebro, neurología, cognición musical, emoción.

Title: Neurology and musical cognition.

\section{Abstract}

This text has been developed based on three articles: "The Neuroscientific Basis of Music: Applications to the Development of Talent and Education" by William Bart and Michael Athernon; "Swinging in the Brain: Shared Neural Substrates for Behaviors Related to Sequencing and Music" by Janata and Grafton; and "Towards a Neural Basis of Music Perception" by Koelsch and Siebel. Additionally, its development is nuanced by other authors and researchers who relate their postulates to the topics reviewed in the first three articles mentioned above. It is worth noting the importance of interdisciplinary work in scientific discovery that can be made for each field of knowledge, constituting a significant contribution to the strengthening of science. In this case, these studies would have important pedagogical implications, particularly for music education, but also for general education, revalidating the appreciation and importance of teaching music in schools.

Keywords: brain, neurology, musical cognition, emotion.

Capera Chilatra, G., Murcia Suárez, M. A., Góngora, D. F., Ruiz, I. A. y Galindo Palma, H. (2010). Gonzalo Sánchez: Testimonio del folclor musical de la Tierra del Bunde. Música, Cultura y Pensamiento, 2(2), 73-87. Ibagué: Conservatorio del Tolima.
17 


\section{Resumen}

La música es uno de los legados más importantes en el Tolima, y sus compositores han contribuido definitivamente a construir este patrimonio. En el municipio del Espinal, "la meca del folclor", Gonzalo Sánchez ha sido protagonista excepcional de su historia, primero como músico de La Divina, la más famosa banda de música de los años 20 en el Tolima, y ya en su edad madura, definiéndose como uno de los más prolíficos compositores de música vernácula del departamento, con cerca de 800 composiciones, en su mayoría inéditas. Resultado de una investigación de historia de vida, el presente artículo recoge el testimonio de la trayectoria artística y educativa de Gonzalo Sánchez, el fundador del Festival del Bunde que revela una vida entera dedicada a la difusión de la identidad regional y del folclor musical del departamento del Tolima.

Palabras clave: Gonzalo Sánchez, compositor tolimense, bandas musicales del Espinal, Festival del Bunde, folclor musical tolimense.

Title: Gonzalo Sánchez: Testimony of folklore music from the Land of Bunde.

\section{Abstract}

Music is one of the most important legacies in Tolima, and its composers have definitely contributed to this heritage. Gonzalo Sánchez has been an important protagonist in the history of folklore music, especially in Espinal, which is known as the mecca of folklore. In the 20's he was as a musician in the most famous band in Tolima called 'La Divina', and as he got older, he became known as one of the department's most prolific composers of vernacular music, composing about 800 works, most of which are unpublished. As a result of an investiga- tion into his life story, this article is a testimony of the artistic and educational life of Gonzalo Sánchez, founder of the Bunde Festival, revealing a lifetime dedicated to the dissemination of regional identity and Tolima's folk music.

Keywords: Gonzalo Sánchez, Tolima's songwriter, musical bands in Espinal, Bunde Festival, Tolima's folk music.

Quiñones, J. A. (2010). La música de los pueblos originarios de América y su relación con el mito, el rito, el juego y la fiesta. Música, Cultura y Pensamiento, 2(2), 89-95. Ibagué: Conservatorio del Tolima.

\section{Resumen}

El artículo busca motivar al lector para que, desde una conciencia histórica que le permita ubicarse en el tiempo y el espacio actual, valore la herencia de las culturas indígenas que nos precedieron, de las que se conserva el legado tradicional a pesar de su desconocimiento en la sociedad moderna. A través de citas de cronistas e intelectuales se reafirma la importancia de incluir en la educación artística la conciencia de pertenecer a un contexto particular, recuperando el respeto por su propia esencia y dándole sentido a la vida y a la identidad cultural. Se propone reflexionar sobre el mito y el rito como elementos vitales para la existencia humana, invitando a que la práctica artística se derive de vivencias, como en las tradiciones originarias de nuestra cultura actual, fuentes de inspiración para la creación poética, no solo para la música y la danza, sino también como prácticas que deben ser recuperadas en las diferentes propuestas educacionales colombianas.

Palabras clave: música indígena, educación artística, mito y rito, danza, juego y fiesta. 
Title: The music of the American indigenous peoples and their relationship with the myths, rituals, play and party.

\section{Abstract}

From a historical awareness that lets us locate ourselves in the current time and space, this article tries to motivate the reader to value the indigenous cultural heritage which has been conserved, despite modern society's ignorance. This paper reaffirms, through the citations of chroniclers and intellectuals, the importance of including the conscience of belonging to a particular context for artistic education, while recovering the respect of self essence and making sense of life and cultural identity. It is argued that myths and rituals can be thought of as vital elements for human existence, inviting artistic practices to be derived from experiences, such as the ancient traditions of our culture, which sare not only a source of inspiration for poetic creation, but also for the creation of music and dance. Such practices must be recovered in the Colombian educational proposal.

Keywords: indigenous music, artistic education, myths and rituals, dance, play and party.

Sánchez Suárez, S. (2010). Bunde tolimense: ¿ritmo o mito? Música, Cultura y Pensamiento, 2(2), 99-112. Ibagué: Conservatorio del Tolima.

\section{Resumen}

En 1914, Alberto Castilla compuso el Bunde Tolimense, obra musical que lo inmortalizó como compositor y que sirvió como modelo de identidad regional. Esta obra musical se convierte en himno del Tolima y a su vez una de las obras más representativas a nivel nacional. Estos acontecimientos fueron lo suficientemente importantes para di- mensionar la obra de Castilla como modelo y referencia, y de esta manera establecerlo como un ritmo regional. La falta de popularización de otros bundes distintos al de Castilla, a pesar de su categorización como ritmo e incluso como género, deja varias interrogantes desde el punto de partida. ¿Como fue el proceso de composición hasta convertirse en himno?, ¿por qué se considera un ritmo ante el poco repertorio?, ¿cuáles son los elementos musicales que caracterizan el Bunde Tolimense? Ante estos interrogantes, más allá del análisis técnico que se realice de la obra de Castilla, se necesita previamente una contextualización histórica del autor y su entorno, identificar los procesos de identidad regional que se vivieron en el país en la primera mitad del siglo $x x$ y las referencias conceptuales acerca de la palabra Bunde.

Palabras clave: música colombiana, bunde tolimense, identidad y música, análisis musical. Alberto Castilla.

Title: Bunde Tolimense: rhythm or myth?

\section{Abstract}

In 1914, Alberto Castilla composed the Tolimense Bunde, a musical work that immortalized him as a composer and served as a model of regional identity. This musical work became Tolima's regional hymn and has become one of the most representative works nationwide, converting Castilla into a model and reference point, and thus establish him as a regional rhythm. The lack of popularity of other bundes that weren't written by Castilla, despite its categorization as a rhythm and even as a genre, leaves several questions. What was the process it undertook from the point of composition to the point where it was converted into a regional hymn? Why is it considered a rhythm despite having very little reper- 
toire? What are the musical elements that characterize the Bunde Tolimense? Faced with these questions, beyond the technical analysis of Castilla's work, a historical contextualization of the author and his environment is needed in order to identify the processes of regional identity that occurred in the country in the first half of the twentieth century, including the conceptual references of the word, Bunde.

Keywords: colombian music, Bunde Tolimense, identity and music, musical analysis, Alberto Castilla.

Ramírez, A. C. (2010). Debussy: otro camino al atonalismo. Música, Cultura y Pensamiento, 2(2), 113-123. Ibagué: Conservatorio del Tolima.

\section{Resumen}

El atonalismo como ruptura de característica música tonal occidental es el tema del presente ensayo. A partir de algunos puntos de referencia histórica desde la Escuela de Manheim, la evolución y declive de la forma sonata, el papel revelador de Wagner, para centrar el foco en la obra de Claude Debussy, analizando los elementos constitutivos de su propuesta sonora, que con la ruptura de los convencionalismos de la morfología europea, la liberación del sistema mayor-menor de la música occidental, $y$ el aprovechamiento de recursos inspirados en culturas musicales como el gamelán, daría inicio al impresionismo, una de las más originales corrientes creadoras, que influenciaría, a los compositores de música occidental del siglo xx.

Palabras clave: impresionismo, armonía impresionista, Claude Debussy, estética francesa comienzos siglo xx.
Title: Debussy: another path to atonalism.

\begin{abstract}
The subject of this essay is atonalism as a rupture of the Western tonal music. From some points of historical reference from the School of Manheim, the evolution and decline of sonata form, the revealing role of Wagner, to center the focus on the work of Claude Debussy, analyzing the elements of the proposal score, which with the rupture of the conventionalisms of the European morphology, the liberation of the major-minor Western music system, and the use of resources inspired by the gamelan musical cultures, would give birth to Impressionism, one of the most original creative currents that would influence Western composers of the Twentieth Century.
\end{abstract}

Keywords: impressionism, harmony, Claude Debussy, impressionist aesthetic early twentieth century French.

Hernández Guayara, A. (2010). Análisis bibliométrico de los Trabajos de Grado de la Licenciatura en Música del Conservatorio del Tolima (2008-2010). Música, Cultura y Pensamiento, 2(2), 127-139. Ibagué: Conservatorio del Tolima.

\section{Resumen}

Este artículo expone los resultados del análisis bibliométrico realizado a 27 trabajos de grado de la Facultad de Educación y Artes del Conservatorio del Tolima. En él se determinaron las dinámicas y apuestas metodológicas desarrolladas en estos trabajos, y su contribución al desarrollo musical local. Asimismo, se identificó el número de estudiantes que ejecutaron el proyecto, directores que los dirigieron, los autores más citados, la línea de investigación ins- 
titucional a la que pertenece cada trabajo y herramientas o instrumentos utilizados para la recolección de la información. Estos datos fueron documentados en una ficha de análisis en formato Excel. El análisis permitió constatar que la dinámica investigativa en los últimos años se ha fortalecido, gracias a la puesta en práctica de estrategias propuestas en el Conservatorio para cualificar la investigación formativa en el nivel de pregrado. Esto ha llevado a la consolidación de trabajos de grado de mayor calidad en su contenido, y diseño respecto a trabajos realizados antes de 2008.

Palabras clave: análisis bibliométrico, trabajos de grado, investigación formativa en el Conservatorio del Tolima, enfoques de investigación, líneas de investigación.

Title: Bibliometric analysis of the Undergraduate Theses for the Bachelor's Degree in Music from the Tolima Conservatory (2008-2010).

\section{Abstract}

This article presents the results of the bibliometric analysis of 27 theses or dissertations from the Faculty of Education and the Arts at the Tolima Conservatory. It identi- fied the dynamics and methodology developed in the theses and their contribution to local music. Moreover, the number of students who carried out the project, directors who directed them, the most cited authors, the line of institutional research to which each thesis belongs, and the tools or instruments used to collect information were all identified. This data was documented in an analysis sheet in Excel. The analysis helped to confirm that the dynamics of the research in recent years has been strengthened, thanks to the implementation of strategies proposed by the Conservatory in order to qualify formative research at an undergraduate level. This promoted the consolidation of higher quality thesis work in terms of content and design with respect to work undertaken before 2008 .

Keywords: bibliometric analysis, theses, research training at the Tolima Conservatory, research approaches, research lines.

\section{Separata}

Ramírez, A. C. (2010). Nocturno Op. 20 para orquesta de cuerdas y oboe. Música, Cultura y Pensamiento, 2(2), 1-12 [separata]. Ibagué: Conservatorio del Tolima. 


\section{1}

Música, Cultura y Pensamiento N. ${ }^{\circ} 3$

\section{Artículos}

Zambrano Rodríguez, L. (2011). El estilo musical en las piezas para piano de Adolfo Mejía. Música, Cultura y Pensamiento, 3(3), 1748. Ibagué: Conservatorio del Tolima.

\section{Resumen}

En este artículo se pretende definir el estilo del compositor colombiano Adolfo Mejía en la escritura de sus piezas para piano. Esta es una tarea que requiere de una descripción analítica de los procesos y técnicas de composición utilizados, para lo cual se debe recurrir a los análisis armónico, formal, contrapuntístico y rítmico de estas obras. Mediante estos análisis se busca desarrollar y sistematizar algoritmos que expliquen la manera como fueron compuestas las piezas para piano de Mejía. El estudio de un estilo se puede abordar desde diferentes puntos de vista; uno, muy general y que se enmarca en el campo de la estética, es el que acude a la contextualización histórica y a la descripción de las características expresivas de la música. También se puede caracterizar un estilo a través de la comparación de un determinado lenguaje con el de otros autores para llegar así a la delimitación de escuelas o grupos. Para comprender un estilo también es válido estudiarlo de manera individual, ahondando en sus características puramente musicales y tratar de entenderlo desde la teoría musical. No se trata de negar las influencias de otros estilos de época o pertenecientes a una escuela determinada, sino, más bien, de realizar un estudio de la manera como un autor, en este caso Adolfo Mejía, Ilega a la elaboración de piezas determinadas y evidenciar así cuáles son los mecanismos o técnicas que le permiten esa escritura.

Palabras clave: estilo musical, análisis formal, análisis armónico, análisis contrapuntístico, análisis rítmico, algoritmos.

Title: The musical style in the pieces for piano by Adolfo Mejía.

\section{Abstract}

This article aims at defining the composition style of the piano pieces by Adolfo Mejía, a Colombian composer. This task requires an analytic description of the processes and techniques used; to accomplish this, a harmonic, formal, contrapuntist and rhythmic analysis is necessary. Through this analysis, the development and systematization of algorithms that explain the way in which these works were composed is looked for. The study of Musical Style can be approached from different viewpoints including a very general one which deals with Aesthetics. It consists of a historic contextualization and a description of the expressive characteristics of music. Another way to define a musical style is by comparing certain languages with those of another composer in order to delimit style groups or schools. A musical style can also be studied individually, delving into its purely musical characteristics in order to try and understand it exclusively from Music Theory. It's not about denying the influence of an époque or school style, but rather finding out how a composer, in this case, Mejía, wrote these piano pieces and discovering the processes and techniques he used.

Keywords: musical style, formal analysis, harmonic analysis, contrapuntist analysis, rhythmic analysis, algorithms. 
Reyes Alvarado, E. El papel de las TICs en la recuperación de sonidos de instrumentos prehispánicos. Música, Cultura y Pensamiento, 3(3), 49-62. Ibagué: Conservatorio del Tolima.

\section{Resumen}

Este artículo hace una reflexión en torno a los sonidos y las músicas ancestrales y propone que estos se pueden recuperar con el grado de precisión que la ciencia y la tecnología permitan, mientras que estas solo son generables en la medida en que se hayan recuperado sus sonidos y existan acuerdos tácitos o predeterminados entre ejecutantes y observadores. Al tratar los instrumentos musicales como sistemas formalizables, y la generación de músicas como proyectos interdisciplinarios, el artículo describe el papel que tienen las Tecnologías de la Información y Comunicaciones (TICs) en los procesos involucrados.

Palabras clave: Informática, cálculo digital, simulación, física de la música, sistemas de tiempo real, instrumentos musicales, musicología.

Title: The role of ICT in the recovery of sounds of pre-Hispanic instruments.

\section{Abstract}

This paper reflects on ancestral sounds and music, stating that ancestral sounds can be recovered, with the degree of precision that science and technology allows. It is important to note that they can only be generated if their sounds are restored, and explicit or implicit agreements between performers and observers exist. Considering musical instruments as formal systems, and the generation of music as interdisciplinary projects, the paper describes the role of information and Communication Technologies in the related process.

Keywords: informatics, digital calculation, simulation, physics of music, real time systems, musical instruments, musicology.

Gaitán Bayona, J. L. (2011). La música de Pala: "para tener la muerte entretenida". Música, Cultura y Pensamiento, 3(3), 65-72. Ibagué: Conservatorio del Tolima.

\section{Resumen}

La música de Pala tiene un poderoso vínculo con la literatura, y especialmente con la poesía. En las canciones de este artista no solo hay uso de metáforas, humor e ironía, sino también intertextualidad con la creación estética de diversos artistas del canon universal. Sus temas principales son el amor, el carpe diem, la historia e idiosincrasia colombiana, y la urgencia de romper con una mentalidad conservadora, inquisitorial y ultracatólica. Su discografía está integrada por Amnesialand (2000), Colombianito (2003), Pala Bras (2006), Yo y ya (2010), y un álbum a dúo con Andrés Correa Ilamado Socios ociosos (2008).

Palabras clave: Pala, música, Colombia, poesía, amor.

Title: Pala's music: 'to entertain the thought of death'.

\footnotetext{
Abstract

Pala's music has a powerful link with literature, especially poetry. In his songs he not only uses metaphors, humor and irony, but also intertextuality with the esthetical creation of diverse artists of universal cannon. He mainly sings about love, carpe diem, Colombian idiosyncrasy and history, and the importance of breaking away from
} 
a conservative, inquisitorial and ultramontane mentality. His discography includes Amnesialand (2000), Colombianito (2003), Pala Bras (2006), Yo y ya (2010), and the duo album with Andrés Correa called, Socios ociosos (2008).

Keywords: Pala, music, Colombia, poetry, love.

Orjuela Quintero, A. (2011). Las músicas del mundo y los derechos de autor, más allá de las fronteras de la invención humana: una búsqueda hacia la propiedad colectiva. Música, Cultura y Pensamiento, 3(3), 73-78. Ibagué: Conservatorio del Tolima.

\section{Resumen}

Artículo que presenta una reflexión en torno a la necesidad de flexibilización y actualización de la noción jurídica y social de la propiedad intelectual y de los derechos de autor, con el propósito de aportar a la búsqueda de una propiedad colectiva que ampare la memoria sonora de las comunidades, dadas las nuevas dinámicas de la industria musical que en la mayoría de los casos desvanece la autoría y el significado de estas manifestaciones para los pueblos, generando modificaciones estructurales en las músicas tradicionales y en sus intérpretes para poderlas comercializar bajo el rótulo de Músicas del Mundo.

Palabras clave: músicas del mundo, derechos de autor, propiedad colectiva, propiedad intelectual, industria musical, músicas tradicionales.

Title: World music and copyright, beyond the borders of human invention: a search for collective ownership.

\section{Abstract}

This article presents a reflection on the need to flexibilize and update the legal and social conception of intellectual property and copyright, in order to contribute to finding a collective property that covers the sound memory of the communities, given that the new dynamics of the music industry, in most cases, blurs authorship rights and the significance of a particular music for the people, in turn, causing structural changes in the traditional music and its performers in order to be able to market it under the label of world music.

Keywords: world music, copyright, collective ownership, intellectual property, music industry, traditional music.

Acosta Arias, D. R., Bernal Espinosa, L. M., Serrano Barceló, M. L. y Galindo Palma, H. (2011). Ernesto Díaz Alméciga (1932-2001), Fundador y director de la Orquesta Sinfónica Juvenil de Colombia: entre el atril y la batuta. Música, Cultura y Pensamiento, 3(3), 79-97. Ibagué: Conservatorio del Tolima.

\section{Resumen}

A partir de este estudio se reconstruye la trayectoria artística y la participación del maestro Ernesto Díaz Alméciga, músico colombiano quien será recordado como parte de la historia de la música nacional por la creación de la Orquesta Sinfónica Juvenil de Colombia entre los años 80 y 90, en el desarrollo de la música de cámara y sinfónica del país, como director orquestal y formador de grandes músicos colombianos. Mediante la recuperación de archivos documentales y entrevistas a quienes conocieron de cerca la vida del maestro, se revela un testimonio digno de ejemplo para las nuevas generaciones de directores, intérpretes y gestores de la música sinfónica en Colombia.

Palabras clave: movimiento sinfónico juvenil, orquestas sinfónicas, dirección orquestal, historia de vida. 
Title: Ernesto Díaz Alméciga (1932 -2001): Founder and director of the Youth Symphonic Orchestra of Colombia: Between the lectern and the baton.

\begin{abstract}
From this study, the artistic trajectory and the participation of maestro Ernesto Díaz Alméciga, a Colombian musician who will be remembered as part of the history of national music for the creation of the $\mathrm{Na}$ tional Youth Orchestra of Colombia in the 80 's and 90's, and the development of Colombian chamber and symphonic music as orchestral director and educator of great Colombian musicians is reconstructed. Through the recollection of archives and interviews with those who knew the maestro, a testimony, worthy of example for new generations of directors, performers and managers of symphonic music in Colombia is revealed.
\end{abstract}

Keywords: youth symphonic movement, symphonic orchestra, orchestral directing, life story.

Tovar Torres, H. G. (2011). Condición física de ingresantes a programas de música del Conservatorio del Tolima. Música, Cultura y Pensamiento, 3(3), 101-113. Ibagué: Conservatorio del Tolima.

\section{Resumen}

El presente estudio pretende determinar la condición física de los estudiantes ingresantes a la educación superior en los programas de Licenciatura en Música y Maestro en Música del Conservatorio del Tolima, durante la temporada semestre B-2011. La misma, se planteó como una investigación de enfoque cuantitativo no experimental, de diseño transeccional de alcance descriptivo. La unidad de análisis del estudio fueron los estudiantes de género masculino ingresan- tes a los programas de Maestro en Música y Licenciatura en Música, población/universo de 20 estudiantes y los cuales fueron seleccionados en un $95 \%$ de manera no probabilística a través de la muestra sujetos-tipo de ambos géneros, en edades comprendidas entre 16 y 24 años. La importancia del estudio radica en que aporta datos esenciales sobre estado de aptitud física de los estudiantes que ingresan a los programas de Licenciatura en Música y Maestro en Música, creando registros inexistentes y siendo fundamentales para identificar a los individuos de riesgo que pueden requerir atención especial, así como ser punto de partida para otros estudios de aptitud física en músicos.

Palabras clave: aptitud física, educación superior, estudiantes de música.

Title: Fitness of entrants to music programs at the Conservatory of Tolima.

\section{Abstract}

This study aims to determine the physical condition of the students that are entering the Higher Education Undergraduate and Master's Degree Programs in Music at the Tolima Conservatory during the second semester, 2011. It was proposed as a quantitative approach to non-experimental research, with a descriptive design that has a wide transactional scope. The target group of the study was male freshmen students enrolled in undergraduate and master's degrees in music, with a population of 20 students who were 95\% non-probabilistically selected through the sample group containing both genders, aged between 16 and 24. The importance of this study is to provide essential data on the physical condition of students entering graduate and undergraduate programs in music in order to create non existing records, which is essential to identify individuals who are 
at risk and may require special attention, as well as being a starting point for other studies regarding the physical fitness of musicians.

Keywords: physical fitness, higher education, music students.

Guarín Ramírez, N. (2011). Evaluación y rediseño de la Licenciatura en Música de la Facultad de Artes del Conservatorio del Tolima. Música, Cultura y Pensamiento, 3(3), 115-131. Ibagué: Conservatorio del Tolima.

\section{Resumen}

El presente artículo corresponde a la evaluación hecha al programa de Licenciatura en Música de la Facultad de Educación y Artes del Conservatorio del Tolima con el fin de conocer si este responde a las necesidades de la región y del país y a las expectativas de los estudiantes. Al realizar esta investigación se tuvo como propósito identificar las fortalezas y debilidades del programa, conocer procesos curriculares, intereses de los estudiantes, saber si los egresados están formados para atender las necesidades del sector y de la región, y valorar el concepto que tienen los empleadores sobre el desempeño profesional de los egresados, constituyéndose en un estudio que permita tomar decisiones orientadas a una renovación curricular. Esta evaluación se realizó como una investigación cualitativa con enfoque etnográfico.

Palabras clave: evaluación, currículo, educación superior y evaluación participativa.

Title: Evaluation and redesign of the Bachelor of Music program of the Faculty of Arts at the Tolima Conservatory.

\begin{abstract}
This article is related to the evaluation performed on the Higher Education Music Degree Programs that correspond to the Faculty of Education and Arts at The Tolima Conservatory in order to see if they meet the needs of the region and the country, as well as the expectations of its students. The purpose of this research was to identify the strengths and weaknesses of the program, learn about curriculum processes and student interests, and find out whether the graduates are trained to meet the needs of the industry and the region, while at the same time assessing the concept that employers have on the professional performance of graduates; in turn, turning it into a study that helps make decisions aimed at curriculum renewal. This evaluation was conducted as a qualitative research with an ethnographic approach.
\end{abstract}

Keywords: assessment, curriculum, higher education, and participatory evaluation.

Niño Castro, G. A. Concierto para Guitarra y Orquesta de Cuerdas del compositor Álvaro Ramírez Sierra. Música, Cultura y Pensamiento, 3(3), 133-159. Ibagué: Conservatorio del Tolima.

\section{Resumen}

Siempre será importante para un intérprete estar en constante renovación del repertorio que usualmente practica y presenta en escena, más aún si en gran parte es inédito o desconocido. Incorporar repertorio inédito o estreno de obras en un concierto, podría evitar saturar a un público que está interesado en escuchar propuestas nuevas y diferentes. El presente artículo plantea el análisis y la reflexión del autor-músico y concertista de guitarra sobre su encuentro 
con la obra inédita del compositor vallecaucano Álvaro Ramírez Sierra, en la que confluyen los aspectos vivenciales, que sirven para dar a conocer su relación con el estilo y lenguaje musical en una de sus obras menos conocidas.

Palabras clave: concierto para guitarra y orquesta de cuerdas, Álvaro Ramírez Sierra, obra inédita.

Title: Guitar and String Orchestra concert from the composer Álvaro Ramírez Sierra.

\section{Abstract}

It is always important for an interpreter to constantly renovate his repertoire that he practices and presents on stage, especially if much of this is unpublished or unknown. Incorporating unpublished works or playing for the first time new works in a concert, can help avoid overwhelming an audience, which is almost always interested in listening to new and different proposals. This article is a reflection from the author's experience as a concert guitarist and his encounter with the unpublished work of composer Álvaro Ramírez Sierra, which brings together the experiential aspects that serve to publicize his relationship with the style and musical language in one of his lesser-known pieces.

Keywords: Colombian composer, guitar and string orchestra concert, Álvaro Ramírez Sierra, unpublished work, score analysis, interpretation.

\section{Separata}

Niño, G. (2011): Concierto para Guitarra y Orquesta de Cuerdas: Álvaro Ramírez Sierra (1932-1991). Música, Cultura y Pensamiento, 3(3), 1-24 [separata]. Ibagué: Conservatorio del Tolima. 


\section{2}

Música, Cultura y Pensamiento N. ${ }^{\circ} 4$

\section{Artículos}

Rojas Rivera, D. C., Suárez León, C. M. y Betancourt, C. A. (2012). Evocando la memoria sonora de Bogotá. Música, Cultura y Pensamiento, 4(4), 13-28. Ibagué: Conservatorio del Tolima.

\section{Resumen}

La investigación titulada "Recuperación del patrimonio sonoro de Bogotá" buscó identificar lugares, prácticas y significaciones representativas del paisaje sonoro de Bogotá a través de las experiencias y saberes de personas mayores que han habitado la ciudad por varias décadas, con el fin de proponer su caracterización desde mitad del siglo xx. La investigación se desarrolló durante cinco conversatorios, realizados en cada una de las localidades de la ciudad de Bogotá: Los Mártires, Santa Fe, Teusaquillo, Chapinero y la Candelaria. Estas fueron escogidas por ser los espacios geográficos desde los cuales se ha desarrollado la ciudad capital en el siglo xx. Para el trabajo se convocaron personas mayores que han habitado Bogotá por varias décadas para, desde la perspectiva de historia cultural a través del testimonio y memoria oral, establecer un diálogo que permita sondear la memoria individual y colectiva de estas personas en relación con sus experiencias, significados e imaginarios del paisaje sonoro bogotano, tomando como referentes diversos lugares representativos de la ciudad y prácticas que involucran elementos sonoros que pueden considerarse constitutivos de la identidad cultural de la misma.
Palabras clave: Memoria sonora, patrimonio cultural intangible, memoria cultural, patrimonio sonoro.

Title: Evoking the sound memory of Bogotá.

\section{Abstract}

The research entitled, "Recovery of the sound heritage of Bogotá" aims to identify places, practices, and meanings that are representative of the soundscape of Bogotá through the experience and knowledge of older people who have inhabited the city for several decades, in order to propose their characterization since the mid-twentieth century. The research was conducted through five conversations in different localities of Bogotá: Los Mártires, Santa Fe, Teusaquillo, Chapinero and La Candelaria. These locations were chosen given that they represent the geographical areas where the city has developed in the twentieth century. Seniors who have lived in Bogotá for several decades were asked to, from the perspective of cultural history through oral testimony and memory, establish a dialogue that one can use to explore the individual and collective memory of these people in connection to experiences, meaning and imaginary soundscape in Bogotá, using, several representative places around the city as a reference, as well as practices involving sound elements that can be considered to constitute its cultural identity.

Keywords: sound memory, intangible cultural heritage, cultural memory, sound heritage.

Uribe Beltrán, C. E. (2012). La chizga: un toque de aprendizaje autónomo musical. Música, Cultura y Pensamiento, 4(4), 29-39. Ibagué: Conservatorio del Tolima. 


\section{Resumen}

Este artículo presenta la reflexión analítica sobre una parte de los resultados del proyecto de investigación denominado "Paisaje musical de la ciudad de Pereira: un mapa sonoro". La chizga se establece como un punto nodal dentro de la configuración del mapa sonoro de la ciudad, en el cual confluyen diversidad de experiencias, saberes, representaciones y motivaciones de músicos que participan de esa vivencia. El proyecto se inició en el año 2008 y se realizó con cinco trabajos de grado y uno de extensión solidaria, tendiente a establecer un estado del arte de los alcances del proyecto formador en las agrupaciones musicales de la ciudad de Pereira, a partir de la oferta educativa durante cerca de 30 años.

Palabras clave: aprendizaje autónomo, currículo, chizga, formación musical, Pereira.

Title: The chizga: a touch of autonomous musical learning.

\begin{abstract}
This article presents an analytical reflection of one part of the results of the project, "Musical Landscape of the City of Pereira: a map of sound". The chizga is a nodal point in the configuration of this map, where a diversity of experiences, knowledge, representations, and motivations of musicians who share this experience converge. The project started in 2008 and included five undergraduate thesis projects and one work of solidary extension, and sought a state of art of the scopes of the educational projects for the different music groups in the city of Pereira, starting from the educational offer for a period of about 30 years in this city.
\end{abstract}

Keywords: autonomous learning, curriculum, music education, chizga, Pereira.
Hernández Guayara, A., García, J. C. y López, T. L. (2012). Documentación sobre la enseñanza del piano en el Conservatorio del Tolima de 1907 a 1940. Música, Cultura y Pensamiento, 4(4), 43-58. Ibagué: Conservatorio del Tolima.

\section{Resumen}

El presente artículo expone las indagaciones preliminares sobre la enseñanza del piano en el Conservatorio del Tolima a partir de 1907 hasta 1940. Dicha información es organizada en diferentes apartados en donde se evidencia la metodología trabajada para desarrollar dicha formación, el sistema de calificación, repertorios utilizados e importantes eventos donde se presentaron los estudiantes de piano de la institución. Al finalizar, se consignan las conclusiones preliminares del proyecto. De igual manera, en este documento, el lector podrá encontrar una serie de cuadros y fotografías de la época, que ilustran los comentarios elaborados por los investigadores.

Palabras clave: historia del Conservatorio del Tolima, enseñanza del piano, repertorios, género.

Title: Documentation on teaching piano at the Tolima Conservatory from 1907 to 1940.

\begin{abstract}
This paper presents the preliminary inquiries into piano teaching at the Tolima Conservatory. This information is organized into various sections evidencing: the work methodology used to develop such training, the grading system, repertoires used, and the important events in which the institution's piano students participated. At the end the project, preliminary findings are presented. The reader can find a series of pictures and period photographs that illustrate the comments made by researchers.
\end{abstract}


Keywords: history of the Tolima Conservatory, teaching piano, repertoires, gender.

Quiñones, J. A., "La herencia musical de los Zenú y el fortalecimiento de la identidad cultural a partir de la educación artística", vol. 4, no. 4, (noviembre), 2012, pp. 59-66.

\section{Resumen}

El artículo forma parte del proyecto Los pueblos de América cantan y bailan de la Asociación Totolincho, desde donde se nutren las relaciones del recuerdo y recuperación de las tecnologías tradicionales (TECTRA), en este caso, desde aquellas del saber hacer musical. Es así como en este artículo se presenta un eco de memoria sobre un instrumento ancestral y milenario, las flautas zenú, desde donde se plantea su distribución global en todo el territorio así denominado, hasta el reconocimiento de la verdadera experticia y maestría de los constructores de tales instrumentos. De este modo, se identifica la asociación entre lo ritual, musical, la danza y la posibilidad de creaciones complejas, lo que visto por nuestra perspectiva contemporánea sin duda no vislumbra siquiera la conexión que los habitantes del complejo hidráulico por naturaleza tenían con su entorno natural y con la comprensión del manejo musical a través de flautas globulares y de pico. Se busca entonces un despertar hacia lo sagrado, lo cotidiano, lo que nace y muere constantemente; el recuerdo del sonido traído desde un milenio atrás, que sin duda pudo quedarse en anaqueles de los mejores museos del país o como en este caso, volverse soplo de vida. Hacerse la pregunta es lo importante; actuar, lo relevante.

Palabras clave: educación artística, cultura zenú, flautas zenú, escalas musicales, comunidad artística, flautas de pico colombianas, cerámica zenú.
Title: The musical heritage of Zenú and the strengthening of cultural identity from arts education.

\section{Abstract}

The article is part of the project, People of America sing and dance, carried out by the Totolincho Association which nurtures the relationship of memory and the retrieval of traditional technologies (TECTRA in Spanish), in this case, from those of musical know-how. Therefore, this paper presents an echo of memories relating to an ancient and millenary instrument, the Zenú Flutes, and its global distribution throughout northern Colombia (Zenú territory), as well as recognizing the true expertise and skill of the instrument's builders. Therefore, we identify the association between ritual, music, dance and the possibility of complex creations, which if seen from our contemporary viewpoint, does not let us realize the natural connection between the dwellers of the hydraulic complex with their natural environment, nor their understanding and management of music through beak and globular flutes. An awakening of the sacred and everyday life, which is constantly being born and dying is sought, the memory of sound from a millennium ago, which, no doubt, could remain on the shelves of the best museums in the country or, as in this case, turn into a breath of life. Asking questions is important, while acting is relevant.

Keywords: artistic education, Zenú culture, Zenú flutes, musical scales, artistic communities, Colombian beak flutes, Zenú ceramic.

Boada Valencia, E. V. (2012). Los bambucos de los nacionalistas colombianos: de Pedro Morales Pino y Emilio Murillo Chapul a Leonor Buenaventura de Valencia. Música, Cultura y Pensamiento, 4(4), 69-88. Ibagué: Conservatorio del Tolima. 


\section{Resumen}

En el proceso de consolidación como repúblicas independientes, el nacionalismo nace como una tendencia en los países de América Latina en el siglo xix. En busca de su identidad cultural, dichos países enmarcan el folclor como una nueva bandera que debe ser equiparada a la de los imaginarios del conocimiento europeo. La escritura de los aires folclóricos nacionales en Colombia para piano, para piano y voz, representan el afianzamiento inicial hacia la música académica de nuestra identidad patria. Este artículo realiza una mirada histórica al bambuco como parte importante de la canción colombiana a finales del siglo xix y principios del siglo $\mathrm{xx}$, haciendo un análisis comparativo entre los bambucos de Pedro Morales Pino, Emilio Murillo y los bambucos tolimenses de la compositora Leonor Buenaventura de Valencia.

Palabras clave: compositores nacionalistas, bambuco, piano, canción, Tolima.

Title: The Bambucos of the Colombian nationalists: from Pedro Morales Pino and Emilio Murillo Chapul to Leonor Buenaventura from Valencia.

\section{Abstract}

In the consolidation process as independent republics, nationalism was born as a trend in Latin American countries in the nineteenth century. In search of their cultural identity, these countries frame folklore as a new flag which must be equated with the imagination of European knowledge. The writing of national folk songs for piano and piano and voice in Colombia represents the initial strengthening of the academic music of our homeland identity. This article takes a historical look at Bambuco as an important part of Colombian song in the late nineteenth and early twentieth centuries, mak- ing a comparative analysis between Pedro Morales Pino's and Emilio Murillo's Bambuco and that of composer Leonor Buenaventura Valencia's Bambuco from the Tolima region.

Keywords: national composers, Bambuco, piano, song, Tolima.

Ramírez, A. C. (2012). El enfoque armónico durante el Romanticismo europeo: enriquecimiento de los medios existentes. Música, Cultura y Pensamiento, 4(4), 89-100. Ibagué: Conservatorio del Tolima.

\section{Resumen}

El pensamiento armónico de los compositores del período romántico estuvo en un principio fuertemente anclado al legado del clasicismo, específicamente en lo referido a la consolidación de las cadencias como medio de estructuración morfológica. Entre otros avances del clasicismo, se puede descubrir en algunas páginas de su repertorio una tendencia a modular por artificios cromáticos o enarmónicos a muy lejanas tonalidades en los desarrollos de las formas de sonata. Avances como este fueron una geoda para futuros compositores como Schumann, Chopin y Schubert, quienes enfocaron sus esfuerzos en descubrir la belleza del cromatismo en secciones que no eran únicamente las de desarrollo. Este intenso y fecundo momento de la historia de la música desborda de lirismo y de un individualismo apoteósico.

Palabras clave: armonía, siglo xIx, romanticismo, tonalismo.

Title: The harmonic approach during European Romanticism: enrichment of existing resources.

\section{Abstract}

The harmonic thinking of composers in the Romantic period was at first strongly an- 
chored to the legacy of classicism, specifically related to the consolidation of the cadences as a means of morphological structuring. Among other advances of classicism, it can be discovered in some pages of its repertoire, a tendency to chromatically or enharmonically modulate music to very distant tonalities in the development of different forms of sonata. Innovations such as these were a geode for future composers such as Schumann, Chopin and Schubert who focused their efforts on discovering the beauty of chromaticism in sections that were not just musical development. This intense and fruitful period in the history of music overflows with lyricism and outstanding individualism.

Keywords: harmony, nineteenth century romanticism, tonalism.

\section{Separata}

Luna Buenaventura, J. P. (2012). Tres obras para piano de Óscar Buenaventura. Música, Cultura y Pensamiento, 4(4), 1-20 [separata]. Ibagué: Conservatorio del Tolima. 


\section{3}

Música, Cultura y Pensamiento N. ${ }^{\circ} 5$

\section{Artículos}

Esquivel Chala, Y. F. y Salinas Arias, B. A. (2013). Memoria e identidad sonora del Resguardo indígena Paéz de Gaitania (Tolima): Relatos de los músicos mayores. Música, Cultura y Pensamiento, 5(5), 13-36. Ibagué: Conservatorio del Tolima.

\section{Resumen}

Este documento se apoya en el trabajo investigativo titulado "Memoria e identidad sonora del Resguardo indígena Paéz de Gaitania (Tolima): relatos de los músicos mayores", realizado en el año 2011. En primer lugar, se reseñan los antecedentes históricos de la música indígena en el departamento del Tolima desde los tiempos precolombinos hasta la actualidad. En segundo lugar, se establecen los aspectos etnográficos generales del resguardo Nasa Wes'x en el presente. Así mismo, se narra la historia de la música de la comunidad, desde su llegada al territorio tolimense a principios del siglo xx, el proceso de aculturación influido por la radio, la asimilación de las músicas foráneas, la evangelización, el conflicto armado, las festividades y las influencias actuales. Finalmente se documenta una pieza musical denominada Bambuco Paéz, que está en proceso de desaparición. Este trabajo puede abrir las puertas para futuras investigaciones sobre músicas indígenas en el Tolima y en otras regiones de Colombia, ayuda a crear un imaginario colectivo del pasado y del presente, invitando a una reflexión crítica e histórica del patrimonio inmaterial del Tolima.

Palabras clave: música indígena, memoria, aculturación, evangelización, conflicto armado.
Title: The memory and identity sound of the Paéz de Gaitania Indigenous Reservation, Tolima: Stories of older musicians.

\section{Abstract}

This document is a synthesis of the thesis "Memory and identity sound of the Paéz de Gaitania Indigenous Reservation, Tolima: Stories of older musicians." written in 2011. First the historical background of the native music in the department of Tolima, from the pre-Columbian times to the present is highlighted. Secondly, the current general aspect of the Nasa Wes'x reservation is established. It also narrates the history of music in their community since their arrival to the Tolima region in the $X X$ century, as well as the process of acculturation influenced by the radio, the assimilation of foreign music, the evangelization, the armed conflict, the festivities, and the present influences. Finally, it documents a musical piece called Bambuco Paéz that is in process of extinction. This work can open the way for other research related to native music in Tolima, helping create an imaginary collective about the past and the present, inviting people to critically and historically reflect on the immaterial patrimony of the department.

Keywords: native music, memory, acculturation, evangelism, armed conflict.

Delgado Urrego, E. M. (2013). El canto del Curaca y cimática: estudio de caso en la comunidad Cofán del municipio de Orito, Putumayo (Colombia). Música, Cultura y Pensamiento, 5(5), 37-47. Ibagué: Conservatorio del Tolima.

\section{Resumen}

La sensación y la percepción son dos principios que hacen parte del desarrollo humano y del proceso por el cual el hombre pro- 
duce y recibe estímulos. Su clasificación o su prioridad dependen del lenguaje que se emplee (humano, animal o formal) para lograr la comunicación. En el caso de la experiencia con el canto de los taitas o curacas de la comunidad de los cofanes, desde la aproximación de la etnomúsica, existen debilidades, ya que, si bien el oyente se acerca desde la apreciación perceptiva-descriptiva y los aspectos musicológicos (organología, melotipo, rasgos de la música occidental y oriental) y culturales, no se precisan las herramientas del análisis formal ni los rasgos propios de la música como arte y ciencia. A diferencia de lo anterior, el fenómeno producido en su sensación y percepción por el canto del curaca se perfila como metamúsica. En la búsqueda de una metodología aplicable para entender el fenómeno del canto de los curacas, se empleó la técnica de observación participante. En el artículo se narra la experiencia desde un marco conceptual de una Teoría del arte como símbolo, tomando como valores los aspectos estéticos en función del Objeto fenoménico, el acto u objeto, y el análisis formal (estructuras musicales como por ejemplo la incipiente A-B, A-B-A, A-B-A-C-A, etc.), desde una perspectiva de Espacialidad-Temporalidad (Unidad-Complejidad-Intensidad).

Palabras clave: análisis musical, arte, ciencia, canto de los curacas, cimática, fenómenos sensitivos y perceptuales, Cofán.

Title: The singing of chief and cymatics: Cofan community case study, Orito municipality - Putumayo (Colombia).

\section{Abstract}

Sensation and perception are two principles that are part of human development and the process by which man produces and receives stimuli. Their classification or priority depends on the language being used (human, animal or formal) to achieve com- munication. In the case of the experience with singing shamans or chiefs of the Cofan community, from an ethno-music approach, there are weaknesses, and even though the listener comes from the perceptive-descriptive appreciation and the musicological (organology, melotype traits with Western and Eastern music) and cultural aspects, they do not need the tools of formal analysis nor traits of music such as art and science, in any cultural context, beyond the parameters set by the formal language of Western music. Unlike the above, the phenomenon produced in its sensation and perception by the chief's singing is profiled as metamusic.

In search of an applicable methodology for understanding thephenomenon of thechief's singing, the researcher uses the technique of participant observation in this article. The experience is narrated with the postulate from a conceptual framework of a Theory of art as a symbol, taking as values, the aesthetic aspects in function of phenomenal object, the act and / or object and formal analysis (e.g. musical structures as the incipient $A B, A B A, A B A C A$ etc.) from a perspective of spatiality - temporality (Unit - complexity - intensity).

Keywords: musical analysis, art and science, chief's son, cymatics, sensory and perceptual phenomena, Cofán.

Quiñones, J. A. (2013). El uso pedagógico del Kamu Purrui para el desarrollo de la Sensibilidad en las nuevas generaciones. Música, Cultura y Pensamiento, 5(5), 49-61. Ibagué: Conservatorio del Tolima.

\section{Resumen}

El artículo muestra parte del desarrollo musical de la comunidad tule, haciendo énfasis en el Kamu Purrui, un aerófono del tipo cañas amarradas (flauta de pan) repre- 
sentativo para esta comunidad, que habita en la frontera entre Panamá y Colombia. El instrumento se acompaña de una maraca denominada "Na", que interpretan las mujeres de la comunidad. La melodía se forma gracias al diálogo alterno entre dos ejecutantes que tienen las partes macho y hembra del instrumento, logrando combinar en ocasiones hasta catorce sonidos en dos juegos del instrumento, de forma que no existe un músico sin el otro, y se convierten en uno en la interpretación. Se propone un recorrido desde el uso pedagógico a través de la interpretación del Kamu Purrui en contextos occidentales y territorios locales, buscando enfatizar en la importancia del reconocimiento y recuperación de las músicas tradicionales como ruta de afianzamiento de la identidad colombiana y latinoamericana.

Palabras clave: comunidad educativa, cultura indígena, libre expresión, juego, capacidad creadora, memoria histórica.

Title: Pedagogic use of Kamu Purrui in the development of sensibility in new generations.

\section{Abstract}

The article shows part of the musical development of the Tule community, emphasizing the Kamu Purrui, a wind instrument made out of reeds tied together (bread flute), which is representative of its community located on the border of Panama and Colombia. The instrument is accompanied by a maraca called "Na", which is usually played by the women in the community. The melody is formed through the alternate dialogue between two performers who each have the female and male parts of the instrument, sometimes managing to combine up to fourteen sounds in two sets of the instrument, meaning that both musicians are needed to interpret the music. A route is proposed from the pedagogical use through the interpretation of Kamu Purrui in Western contexts and local territories, seeking to emphasize the importance of recognition and retrieval of traditional music as a way to secure the Colombian and Latin American identity.

Keywords: education community, indigenous culture, free speech, game, creative capacity, historical memory.

Molina, O. J. (2013). La Quena, expresión artística de la música colombiana. Música, Cultura y Pensamiento, 5(5), 63-84. Ibagué: Conservatorio del Tolima.

\section{Resumen}

El presente artículo pretende dar una aproximación sobre la presencia de la quena en Colombia desde 1970 hasta la actualidad y al mismo tiempo rastrear el trabajo de los distintos luthiers e intérpretes que mantienen viva la historia de este instrumento musical en el territorio nacional. De manera breve se introducen aspectos sobre su procedencia, evolución en cuanto a construcción e interpretación, para seguidamente indagar sobre su impacto dentro de la música colombiana. Este es el comienzo de un estudio más amplio dedicado a la quena dentro de la música colombiana.

Palabras clave: quena, Colombia, música latinoamericana, memoria cultural, comunidad artística.

Title: The Quena, artistic expression in Colombian music.

\section{Abstract}

This article aims to give an approximation about the presence of the "Quena" in Colombia since 1970 to the present, while at the same time, trying to trace the work of several luthiers and performers who keep 
the history of this musical instrument in the country alive. Briefly, some aspects regarding its origin and evolution are introduced (in terms of construction and interpretation), in order to investigate the impact that the Quena has had on Colombian music. This is the beginning of a wider study dedicated to the Quena in Colombian music.

Keywords: quena, Colombia, Latin-American music, cultural memory, artistic community.

Leal, C. D. y Leal Castro, A. (2013). La Modernidad y la Postmodernidad: una discusión vigente. Música, Cultura y Pensamiento, 5(5), 87-97. Ibagué: Conservatorio del Tolima.

\section{Resumen}

La reflexión sobre las nociones de modernidad y posmodernidad en Occidente está presente en los albores del siglo xxı, momento en el que aún no se sabe si actualmente se asiste a una real ruptura epocal, o si la posmodernidad no es nada más que un pliegue de la modernidad (Díaz, 2009). En algunas disquisiciones se vislumbra la idea de que la posmodernidad es un desafío a los ideales y axiomas modernos, es una repulsión de los paradigmas de la modernidad, de manera que se muestra como una ruptura o discontinuidad que pone de manifiesto la crisis de la modernidad. La posmodernidad, en esta línea de sentido, se vislumbra como una época de cambio, como un momento de transformación cultural que marca un distanciamiento respecto de la modernidad y que nos invita a pensar de manera ineluctable en lo dicho por Óscar Wilde: que vivimos en una época de superficies, en una época líquida, en una época light. Pero, por otro lado, hay quienes asumen que la posmodernidad no es más que una conti- nuación al extremo, una radicalización de las aventuras estéticas y culturales modernas, de manera que el posmodernismo no es más que una elongación de la era moderna, que entre una y otra noción el meollo es más de énfasis. Lo cierto es que resulta complejo, por no decir impensable, tener una visión acaparadora y pretensiosamente unívoca de estas dos nociones que, si bien han sido ampliamente discutidas y reflexionadas hacía tiempo, en países latinoamericanos como Argentina hicieron "eclosión a mediados de la década de 1980" (Díaz, 2009, p. 10), es decir, de una manera extemporánea, como aconteció también en Colombia, país en el que al decir del profesor Fabio López de la Roche, tan solo dos décadas antes, a partir de los años sesenta, los procesos de modernización y las dinámicas culturales de la modernidad comienzan a ser experimentadas masivamente por la sociedad colombiana (1998).

Palabras clave: modernidad, postmodernidad, sociedad, cultura.

Title: Modernity and postmodernity: a current discussion.

\section{Abstract}

The reflection on the notions of modernity and postmodernity in the West is present in the early Twenty-First Century, at which time it is not yet known if there is currently a real epochal rupture, or if postmodernism is nothing more than a fold of modernity (Díaz, 2009). In some disquisitions, the idea that postmodernism is a challenge to the modern ideals and axioms can be seen. It is a repulsion of the paradigms of modernity, so it is shown as a break or discontinuity that reveals the crisis of modernity. In these terms, postmodernism is seen as a time of change, as a moment of cultural transformation that marks a distancing from Modernity and invites us to 
think about what Oscar Wilde said: that we live in a superficial epoch, in a liquid epoch, in a light epoch. But on the other hand, there are those who assume that postmodernism is merely a continuation to the extreme, a radicalization of modern aesthetic and cultural adventures, meaning that postmodernism is merely an elongation of the modern era and that between different conceptions there is a core notion of emphasis. The truth is that it is complex, if not unthinkable, to have a hoarding and pretentiously unique vision of these two notions. Although, they have been widely discussed and reflected for some time, in Latin American countries like Argentina, they did "exploded in the mid-1980s" (Díaz, 2009:10), in an extemporaneous way, as it happened in Colombia, a country in which, according to professor Fabio López de la Roche, just two decades ago, since the 1960s, the processes of modernization and cultural dynamics of modernity began to be massively experienced by Colombian society.

Keywords: modernity, postmodernity, society, culture.

Salamanca, D. S. (2013). ¿Somos Poetas? Música, Cultura y Pensamiento, 5(5), 99-109. Ibagué: Conservatorio del Tolima.

\section{Resumen}

En el presente artículo se abre una reflexión sobre la música y los músicos a partir de la pregunta inicial que se instaura desde el título que se presenta. La pregunta va dirigida a todos aquellos que tengan a la música como estilo de vida, y a quienes les consagran su existencia desde alguna de las múltiples posibilidades abiertas para que así suceda. Se abre a partir de esta pregunta inicial un camino hacia el preguntar y la reflexión desde la perspectiva presentada en la conferencia
El origen de la obra de arte, pronunciada en 1936 por el filósofo Martin Heidegger. Finalmente, se volverá a plantear la pregunta inicial y se dejará abierta a la luz de lo reflexionado y a consideración del lector.

Palabras clave: música, poetizar, arte, obra, cuidador, creador, verdad.

Title: Are we poets?

\section{Abstract}

The present article offers a reflection on music and musicians, starting with the initial question presented in the title. The question is formulated to all those who find in music a way of life and build their existences on one or more of the multiple possibilities for this to happen. The initial question presented in the title, opens a path of questioning and reflecting based on Martin Heidegger's conference, The origin of the work of art from 1936. Finally, we will be asking the main question once again, leaving it open to the reflections and considerations of the reader.

Keywords: music, poeticize, art, artwork, preserver, creator, truth.

Beltrán Reyes, C. E. (2013). La música en los grandes matemáticos de Occidente. Música, Cultura y Pensamiento, 5(5), 111-117. Ibagué: Conservatorio del Tolima.

\section{Resumen}

Los grandes físico-matemáticos de Occidente como Fourier, Euler, Mersenne, D’Alembert, Galileo, Lagrange y Bernoulli, nunca estuvieron ajenos a la música. Prueba de esto son sus innumerables tratados, libros o compendios que versaron sobre temas como la proporción armónica, el sonido musical, la tensión de las cuerdas, la escala común y la numérica, o las cuerdas accidentales. Ya desde la Antigüedad 
existen referencias que informan que la escuela pitagórica estaba influenciada por sus conocimientos sobre las medias (aritmética, geométrica y armónica), las cuales se habían retomado para la escala numérica llamada hoy Diatónica (Guthrie, 1999, p. 17). En el presente artículo se pretende explorar la forma como la música ha sido tratada por estos matemáticos.

Palabras clave: proporción, armonía, escala numérica, escala cromática, relaciones numéricas.

Title: Music in the great Western mathematicians.

\begin{abstract}
Great Western mathematicians and physicists, such as Fourier, Euler, Mersenne, Galileo, D’Alembert, Bernoulli, were never oblivious to music. Proof of this can be seen in the uncountable treaties, books or compendiums that deal with topics like the harmonic proportion, musical sound, strings tension, the common and numeric scale, or accidental strings. Since ancient times there are references that suggest that the Pythagorean school was influenced by their knowledge of measurements (arithmetic, geometric and harmonic), which were re-used for the numerical scale now called Diatonic (Guthrie, 1999, p. 17). This article is intended to explore how mathematicians have treated music.
\end{abstract}

Keywords: proportion, harmony, numerical scale, chromatic scale, numerical relationships.

Ospina Romero, S. (2013). La obra musical de Luis Antonio Calvo. Música, Cultura y Pensamiento, 5(5), 121-154. Ibagué: Conservatorio del Tolima.

\section{Resumen}

El presente artículo presenta un estudio musicológico de la obra del compositor colombiano Luis Antonio Calvo (1882-1945) organizado en cuatro secciones: a) la dilucidación del legado estilístico que recibió, en especial en lo relacionado con el romanticismo pianístico europeo del siglo xıx; b) la discusión en torno al carácter simultáneamente actual y anacrónico de su música; c) el análisis musical propiamente dicho, en términos de ritmo, melodía, armonía, timbre, forma y carácter lírico; y d) la consideración del papel que jugó su música en el florecimiento de los discursos sobre la música nacional colombiana en los años 40 del siglo $x$.

Palabras clave: Luis Antonio Calvo, musicología, música nacional, música colombiana.

Title: The musical artwork of Luis Antonio Calvo.

\begin{abstract}
The following article presents a musicological study of the work of Colombian composer, Luis Antonio Calvo (1882-1945). The article comprises four sections: a) the elucidation of the stylistic legacy he embraced, particularly, in relation to the European pianistic romanticism of the 19th century; b) the examination of the stylistic mood of his music, simultaneously contemporary and anachronic; c) the musical analysis itself, specifically in terms of rhythm, melody, harmony, form, and lyrics; and d) the consideration of the role of his music in relation to the debates around Colombian national music in the $1940 \mathrm{~s}$
\end{abstract}

Keywords: Luis Antonio Calvo, musicology, national music, Colombian music. 
Ávila Roa, J. A. (2013). Relación entre la actitud postural y el desempeño frente al piano a partir de la técnica Alexander. Música, Cultura y Pensamiento, 5(5), 155-175. Ibagué: Conservatorio del Tolima.

\section{Resumen}

Se le atribuye una gran importancia a la Técnica Alexander, debido a la orientación que quiere llevar a cabo en la conciencia de cada persona para desarrollar sus actividades. Esta técnica, enseña al pianista a mantener un proceso postural activo durante la preparación técnica y contextual de las obras a interpretar. A partir de esta investigación se creó una guía interactiva que muestra un proceso por medio del cual, con la Técnica Alexander, se crean unas condiciones y una conciencia de sí mismo, generando una actitud nueva al tocar el piano con el cuerpo en su totalidad, pensando en un sistema completo y dirigido. Este proyecto indica cómo reeducar el cuerpo, y propone alternativas para dejar atrás los malos hábitos corporales causados por el mal uso del mismo, ayudándolo a recobrar poco a poco su postura natural. Esta investigación es de carácter etnográfico, teniendo como enfoque un análisis cualitativo de tipo descriptivo.

Palabras clave: Técnica Alexander, reeducación postural, piano, experiencia sensorial corporal.

Title: The relationship between the postural attitude and piano performance based on the Alexander Technique.

\footnotetext{
Abstract

The Alexander Technique has been considered to be of great importance due to the factor of awareness that each person achieves on the realization of activities.
}

This technique teaches the pianist to maintain an active postural process during the technical and contextual preparation of the works being interpreted. An interactive guide was created as a result of this research, which shows the process of how, through the Alexander Technique, one develops self-awareness while creating conditions that generate a new attitude towards playing with the whole body in a systemic and directed way. This Project shows how to reeducate the body and suggests ways to leave behind the bad corporal habits caused by the misuse of one's self, leading to the gradual recovery of one's natural posture. Considering the focus on descriptive qualitative analysis, this research is essentially ethnographic in nature.

Keywords: Alexander Technique, postural reeducation, piano, corporal sense experiences.

\section{Reseñas}

Niño Castro, G. A. (2013). Perilla, J. (Ed.), "La Guitarra clásica en la Radio Nacional de Colombia 1968-1978” (CD). Música, Cultura y Pensamiento, 5(5), 179-181. Ibagué: Conservatorio del Tolima.

Galindo Palma, H. (2013). Cuartas Coymat, Á. y Caro Greiffenstein (trad.), "El Conde de Gabriac en Ibagué". Música, Cultura y Pensamiento, 5(5), 183-185. Ibagué: Conservatorio del Tolima.

\section{Separata}

Vivas Barrera, M. C. (2013). Colcorpia: Para tres voces, percusión y computador con tratamiento sonoro en tiempo real. Música, Cultura y Pensamiento, 5(5), 1-20 [separata]. Ibagué: Conservatorio del Tolima. 


\section{Índice por autor}

A

Acosta Arias, D. R., Bernal Espinosa, L. M., Serrano Barceló, M. L. y Galindo Palma, H. (2011). Ernesto Díaz Alméciga (1932-2001), Fundador y director de la Orquesta Sinfónica Juvenil de Colombia: Entre el atril y la batuta. Música, Cultura y Pensamiento, 3(3), 79-97. Ibagué: Conservatorio del Tolima.

Alarcón, J. G. (2009). Fantasía sobre Juan el Bautista para órgano. Música, Cultura y Pensamiento, 1(1), 1-20 [Separata]. Ibagué: Conservatorio del Tolima.

Alarcón Carreño, J. G. (2010). Reflexión histórica de la dirección sinfónica en Colombia: Directores destacados. Música, Cultura y Pensamiento, 2(2), 45-53. Ibagué: Conservatorio del Tolima.

Ávila Roa, J. A. (2013). Relación entre la actitud postural y el desempeño frente al piano a partir de la técnica Alexander. Música, Cultura y Pensamiento, 5(5), 155-175. Ibagué: Conservatorio del Tolima.

\section{B}

Beltrán Agudelo, L. A., Guarín Ramírez, N., Carrión Tovar, M. Á. y Galindo Palma, H. (2009). Línea de investigación en Historia y Patrimonio del Conservatorio del Tolima: aproximaciones teórico-metodológicas. Música, Cultura y Pensamiento, 1(1), 35-47. Ibagué: Conservatorio del Tolima.

Beltrán Agudelo, L. A., Güisa, M. A., Bautista, S. I. y Luna, M. A. (2009). Vicente Sanchis Sanz: Leyenda viva de una época dorada. Música, Cultura y Pensamiento, 1(1), 75-89. Ibagué: Conservatorio del Tolima.

Beltrán Reyes, C. E. (2013). La música en los grandes matemáticos de Occidente. Música, Cultura y Pensamiento, 5(5), 111-117. Ibagué: Conservatorio del Tolima.

Boada Valencia, E. V. (2012). Los bambucos de los nacionalistas colombianos: de Pedro Morales Pino y Emilio Murillo Chapul a Leonor Buenaventura de Valencia. Música, Cultura y Pensamiento, 4(4), 69-88. Ibagué: Conservatorio del Tolima.

\section{C}

Cárdenas Soler, R. N. (2010). Neurología y cognición musical. Música, Cultura y Pensamiento, 2(2), 61-69. Ibagué: Conservatorio del Tolima.

Capera Chilatra, G., Murcia Suárez, M. A., Góngora, D. F., Ruiz, I. A. y Galindo Palma, H. (2010). Gonzalo Sánchez: Testimonio del folclor musical de la Tierra del Bunde. Música, Cultura y Pensamiento, 2(2), 7387. Ibagué: Conservatorio del Tolima.

\section{D}

Delgado Urrego, E. M. (2013). El canto del Curaca y cimática: estudio de caso en la comunidad Cofán del municipio de Orito - Putumayo (Colombia). Música, Cultura y Pensamiento, 5(5), 37-47. Ibagué: Conservatorio del Tolima.

\section{E}

Esquivel Chala, Y. F. y Salinas Arias, B. A. (2013). Memoria e identidad sonora del Resguardo indígena Paéz de Gaitania (Tolima): Relatos de los músicos mayores. Música, Cultura y Pensamiento, 5(5), 13-36. Ibagué: Conservatorio del Tolima.

\section{G}

Gaitán Bayona, J. L. (2011). La música de Pala: "para tener la muerte entretenida". Música, Cultura y Pensamiento, 3(3), 65-72. Ibagué: Conservatorio del Tolima.

Galindo Palma, H. (2009). Instrumentarium: Las culturas tradicionales vistas desde el patrimonio instrumental musical. Música, Cultura y Pensamiento, 1(1), 99-111. Ibagué: Conservatorio del Tolima.

Galindo Palma, H. (2013). Cuartas Coymat, Á. y Caro Greiffenstein (trad.), "El Conde de Gabriac en Ibagué”. Música, Cultura y Pensamiento, 5(5), 183-185. Ibagué: Conservatorio del Tolima.

Gil, F. (2009). Congresos Nacionales de la Música, 1936-1937. Música, Cultura y Pensamiento, 1(1), 13-34. Ibagué: Conservatorio del Tolima.

Guarín Ramírez, N. (2011). Evaluación y rediseño de la Licenciatura en Música de la Facultad de Artes del Conservatorio del Tolima. Música, Cultura y Pensamiento, 3(3), 115-131. Ibagué: Conservatorio del Tolima. 
$\mathbf{H}$

Hernández Guayara, A. y Varón, A. P. (2009). Álvaro Ramírez Sierra: Crónica de un compositor vanguardista colombiano. Música, Cultura y Pensamiento, 1(1), 91-97. Ibagué: Conservatorio del Tolima.

Hernández Guayara, A. (2010). Análisis bibliométrico de los Trabajos de Grado de la Licenciatura en Música del Conservatorio del Tolima (2008-2010). Música, Cultura y Pensamiento, 2(2), 127-139. Ibagué: Conservatorio del Tolima.

Hernández Guayara, A., García, J. C. y López, T. L. (2012). Documentación sobre la enseñanza del piano en el Conservatorio del Tolima de 1907 a 1940. Música, Cultura y Pensamiento, 4(4), 43-58. Ibagué: Conservatorio del Tolima.

\section{$\mathbf{L}$}

Leal Castro, C. D. (2010). La autoevaluación en el docente universitario: una actividad indispensable para la cualificación de los procesos educativos. Música, Cultura y Pensamiento, 2(2), 55-60. Ibagué: Conservatorio del Tolima.

Leal, C. D. y Leal Castro, A. (2013). La Modernidad y la Postmodernidad: una discusión vigente. Música, Cultura y Pensamiento, 5(5), 87-97. Ibagué: Conservatorio del Tolima.

Londoño Fernández, M.E. (2009). Memoria colectiva y músicas locales en una perspectiva de desarrollo humano. Música, Cultura y Pensamiento, 1(1), 35-47. Ibagué: Conservatorio del Tolima.

Luna Buenaventura, J. P. (2012). Tres obras para piano de Óscar Buenaventura. Música, Cultura y Pensamiento, 4(4), 1-20 [separata]. Ibagué: Conservatorio del Tolima.

\section{M}

Molina, O. J. (2013). La Quena, expresión artística de la música colombiana. Música, Cultura y Pensamiento, 5(5), 63-84. Ibagué: Conservatorio del Tolima.

\section{$\mathbf{N}$}

Niño Castro, G. A. Concierto para Guitarra y Orquesta de Cuerdas del compositor Álvaro Ramírez Sierra. Música, Cultura y Pensamiento, 3(3), 133-159. Ibagué: Conservatorio del Tolima.
Niño, G. (2011). Concierto para Guitarra y Orquesta de Cuerdas: Álvaro Ramírez Sierra (1932-1991). Música, Cultura y Pensamiento, 3(3), 1-24 [separata]. Ibagué: Conservatorio del Tolima.

Niño Castro, G. A. (2013). Perilla, J. (Ed.), “La Guitarra clásica en la Radio Nacional de Colombia 1968-1978" (CD). Música, Cultura y Pensamiento, 5(5), 179-181. Ibagué: Conservatorio del Tolima.

\section{0}

Orjuela Quintero, A. (2011). Las músicas del mundo y los derechos de autor, más allá de las fronteras de la invención humana: una búsqueda hacia la propiedad colectiva. Música, Cultura y Pensamiento, 3(3), 73-78. Ibagué: Conservatorio del Tolima.

Ospina Romero, S. (2013). La obra musical de Luis Antonio Calvo. Música, Cultura y Pensamiento, 5(5), 121-154. Ibagué: Conservatorio del Tolima.

\section{Q}

Quevedo Urrea, J. (2010). Memorias documentales del sonido inédito: algunos aspectos técnicos documentales y jurídicos. Música, Cultura y Pensamiento, 2(2), 17-30. Ibagué: Conservatorio del Tolima.

Quiñones, J. A. (2010). La música de los pueblos originarios de América y su relación con el mito, el rito, el juego y la fiesta. Música, Cultura y Pensamiento, 2(2), 89-95. Ibagué: Conservatorio del Tolima.

Quiñones, J. A., "La herencia musical de los Zenú y el fortalecimiento de la identidad cultural a partir de la educación artística”, vol. 4, no. 4, (noviembre), 2012, pp. 59-66.

Quiñones, J. A. (2013). El uso pedagógico del Kamu Purrui para el desarrollo de la Sensibilidad en las nuevas generaciones. Música, Cultura y Pensamiento, 5(5), 49-61. Ibagué: Conservatorio del Tolima.

\section{$\mathbf{R}$}

Ramírez Méndez, A. C. (2009). Suite Op. 18: Una aproximación a los ritmos andinos desde la armonía moderna. Música, Cultura y Pensamiento, 1(1), 131138. Ibagué: Conservatorio del Tolima.

Ramírez, A. C. (2010). Debussy: otro camino al ato41 nalismo. Música, Cultura y Pensamiento, 2(2), 113-123. Ibagué: Conservatorio del Tolima. 
Ramírez, A. C. (2010). Nocturno Op. 20 para orquesta de cuerdas y oboe. Música, Cultura y Pensamiento, 2(2), 1-12 [separata]. Ibagué: Conservatorio del Tolima.

Ramírez, A. C. (2012). El enfoque armónico durante el Romanticismo europeo: enriquecimiento de los medios existentes. Música, Cultura y Pensamiento, 4(4), 89-100. Ibagué: Conservatorio del Tolima.

Reyes Alvarado, E. El papel de las TICs en la recuperación de sonidos de instrumentos prehispánicos. Música, Cultura y Pensamiento, 3(3), 49-62. Ibagué: Conservatorio del Tolima.

Rojas Rivera, D. C., Suárez León, C. M. y Betancourt, C. A. (2012). Evocando la memoria sonora de Bogotá. Música, Cultura y Pensamiento, 4(4), 13-28. Ibagué: Conservatorio del Tolima.

$S$

Salamanca, D. S. (2013). ¿Somos Poetas? Música, Cultura y Pensamiento, 5(5), 99-109. Ibagué: Conservatorio del Tolima.

Sánchez Suárez, S. (2009). Reflexión histórica de las formas de la escritura musical del bambuco, entre el colonialismo y la República en Colombia. Música, Cultura y Pensamiento, 1(1), 115-130. Ibagué: Conservatorio del Tolima.

Sánchez Suárez, S. (2010). Bunde tolimense: ¿ritmo o mito? Música, Cultura y Pensamiento, 2(2), 99-112. Ibagué: Conservatorio del Tolima.
Sossa Santos, J. (2010). Pedagogía del acontecimiento: una experiencia de educación no formal para las músicas regionales. Música, Cultura y Pensamiento, 2(2), 31-44. Ibagué: Conservatorio del Tolima.

\section{$\mathbf{T}$}

Tovar Torres, H. G. (2011). Condición física de ingresantes a programas de música del Conservatorio del Tolima. Música, Cultura y Pensamiento, 3(3), 101-113. Ibagué: Conservatorio del Tolima.

\section{U}

Uribe Beltrán, C. E. (2012). La chizga: un toque de aprendizaje autónomo musical. Música, Cultura y Pensamiento, 4(4), 29-39. Ibagué: Conservatorio del Tolima.

\section{V}

Vivas Barrera, M. C. (2013). Colcorpia: Para tres voces, percusión y computador con tratamiento sonoro en tiempo real. Música, Cultura y Pensamiento, 5(5), 1-20 [separata]. Ibagué: Conservatorio del Tolima.

\section{Z}

Zambrano Rodríguez, L. (2011). El estilo musical en las piezas para piano de Adolfo Mejía. Música, Cultura y Pensamiento, 3(3), 17-48. Ibagué: Conservatorio del Tolima. 


\section{Índice temático}

\section{Música y Pensamiento}

Gil, F. (2009). Congresos Nacionales de la Música, 1936-1937. Música, Cultura y Pensamiento, 1(1), 13-34. Ibagué: Conservatorio del Tolima.

Beltrán Agudelo, L. A., Guarín Ramírez, N., Carrión Tovar, M. Á. y Galindo Palma, H. (2009). Línea de investigación en Historia y Patrimonio del Conservatorio del Tolima: aproximaciones teórico-metodológicas. Música, Cultura y Pensamiento, 1(1), 35-47. Ibagué: Conservatorio del Tolima.

Quevedo Urrea, J. (2010). Memorias documentales del sonido inédito: algunos aspectos técnicos documentales y jurídicos. Música, Cultura y Pensamiento, 2(2), 17-30. Ibagué: Conservatorio del Tolima.

Sossa Santos, J. (2010). Pedagogía del acontecimiento: una experiencia de educación no formal para las músicas regionales. Música, Cultura y Pensamiento, 2(2), 31-44. Ibagué: Conservatorio del Tolima.

Alarcón Carreño, J. G. (2010). Reflexión histórica de la dirección sinfónica en Colombia: Directores destacados. Música, Cultura y Pensamiento, 2(2), 45-53. Ibagué: Conservatorio del Tolima.

Leal Castro, C. D. (2010). La autoevaluación en el docente universitario: una actividad indispensable para la cualificación de los procesos educativos. Música, Cultura y Pensamiento, 2(2), 55-60. Ibagué: Conservatorio del Tolima.

Cárdenas Soler, R. N. (2010). Neurología y cognición musical. Música, Cultura y Pensamiento, 2(2), 61-69. Ibagué: Conservatorio del Tolima.

Zambrano Rodríguez, L. (2011). El estilo musical en las piezas para piano de Adolfo Mejía. Música, Cultura y Pensamiento, 3(3), 17-48. Ibagué: Conservatorio del Tolima.

Reyes Alvarado, E. El papel de las TICs en la recuperación de sonidos de instrumentos prehis- pánicos. Música, Cultura y Pensamiento, 3(3), 49-62. Ibagué: Conservatorio del Tolima.

Hernández Guayara, A., García, J. C. y López, T. L. (2012). Documentación sobre la enseñanza del piano en el Conservatorio del Tolima de 1907 a 1940. Música, Cultura y Pensamiento, 4(4), 43-58. Ibagué: Conservatorio del Tolima.

Quiñones, J. A., “La herencia musical de los Zenú y el fortalecimiento de la identidad cultural a partir de la educación artística”, vol. 4, no. 4, (noviembre), 2012, pp. 59-66.

Leal, C. D. y Leal Castro, A. (2013). La Modernidad y la Postmodernidad: una discusión vigente. Música, Cultura y Pensamiento, 5(5), 87-97. Ibagué: Conservatorio del Tolima.

Salamanca, D. S. (2013). ¿Somos Poetas? Música, Cultura y Pensamiento, 5(5), 99-109. Ibagué: Conservatorio del Tolima.

Beltrán Reyes, C. E. (2013). La música en los grandes matemáticos de Occidente. Música, Cultura y Pensamiento, 5(5), 111-117. Ibagué: Conservatorio del Tolima.

\section{Música y Cultura}

Londoño Fernández, M. E. (2009). Memoria colectiva y músicas locales en una perspectiva de desarrollo humano. Música, Cultura y Pensamiento, 1(1), 35-47. Ibagué: Conservatorio del Tolima.

Beltrán Agudelo, L. A., Millán, Á. J., Rivas Quijano, D. E., Espinosa, H. (2009). Amina Melendro de Pulecio: La legendaria madrina de la música. "Un compromiso con la historia". Música, Cultura y Pensamiento, 1(1), 65-74. Ibagué: Conservatorio del Tolima.

Beltrán Agudelo, L. A., Güisa, M. A., Bautista, S. I. y Luna, M. A. (2009). Vicente Sanchis Sanz: Leyenda viva de una época dorada. Música, Cultura y Pensamiento, 1(1), 75-89. Ibagué: Conservatorio del Tolima.

Hernández Guayara, A. y Varón, A. P. (2009). Álvaro Ramírez Sierra: Crónica de un compositor vanguardista colombiano. Música, Cultura y Pensamiento, 1(1), 91-97. Ibagué: Conservatorio del Tolima.

Galindo Palma, H. (2009). Instrumentarium: Las culturas tradicionales vistas desde el patrimonio instrumental musical. Música, Cultura y Pensamiento, 1(1), 99-111. Ibagué: Conservatorio del Tolima. 
Capera Chilatra, G., Murcia Suárez, M. A., Góngora, D. F., Ruiz, I. A. y Galindo Palma, H. (2010). Gonzalo Sánchez: Testimonio del folclor musical de la Tierra del Bunde. Música, Cultura y Pensamiento, 2(2), 73-87. Ibagué: Conservatorio del Tolima.

Quiñones, J. A. (2010). La música de los pueblos originarios de América y su relación con el mito, el rito, el juego y la fiesta. Música, Cultura y Pensamiento, 2(2), 89-95. Ibagué: Conservatorio del Tolima.

Gaitán Bayona, J. L. (2011). La música de Pala: "para tener la muerte entretenida". Música, Cultura y Pensamiento, 3(3), 65-72. Ibagué: Conservatorio del Tolima.

Orjuela Quintero, A. (2011). Las músicas del mundo y los derechos de autor, más allá de las fronteras de la invención humana: una búsqueda hacia la propiedad colectiva. Música, Cultura y Pensamiento, 3(3), 73-78. Ibagué: Conservatorio del Tolima.

Acosta Arias, D. R., Bernal Espinosa, L. M., Serrano Barceló, M. L. y Galindo Palma, H. (2011). Ernesto Díaz Alméciga (1932-2001), Fundador y director de la Orquesta Sinfónica Juvenil de Colombia: entre el atril y la batuta. Música, Cultura y Pensamiento, 3(3), 79-97. Ibagué: Conservatorio del Tolima.

Rojas Rivera, D. C., Suárez León, C. M. y Betancourt, C. A. (2012). Evocando la memoria sonora de Bogotá. Música, Cultura y Pensamiento, 4(4), 13-28. Ibagué: Conservatorio del Tolima.

Uribe Beltrán, C. E. (2012). La chizga: un toque de aprendizaje autónomo musical. Música, Cultura y Pensamiento, 4(4), 29-39. Ibagué: Conservatorio del Tolima.

Esquivel Chala, Y. F. y Salinas Arias, B. A. (2013). Memoria e identidad sonora del Resguardo indígena Paéz de Gaitania (Tolima): Relatos de los músicos mayores. Música, Cultura y Pensamiento, 5(5), 13-36. Ibagué: Conservatorio del Tolima.

Delgado Urrego, E. M. (2013). El canto del Curaca y cimática: estudio de caso en la comunidad Cofán del municipio de Orito - Putumayo (Colombia). Música, Cultura y Pensamiento, 5(5), 37-47. Ibagué: Conservatorio del Tolima.

Quiñones, J. A. (2013). El uso pedagógico del Kamu Purrui para el desarrollo de la Sensibilidad en las nuevas generaciones. Música, Cultura y Pensamiento, 5(5), 49-61. Ibagué: Conservatorio del Tolima.

Molina, O. J. (2013). La Quena, expresión artística de la música colombiana. Música, Cultura y Pensamiento, 5(5), 63-84. Ibagué: Conservatorio del Tolima.

\section{Música en clave}

Sánchez Suárez, S. (2009). Reflexión histórica de las formas de la escritura musical del bambuco, entre el colonialismo y la República en Colombia. Música, Cultura y Pensamiento, 1(1), 115-130. Ibagué: Conservatorio del Tolima.

Ramírez Méndez, A. C. (2009). Suite Op. 18: Una aproximación a los ritmos andinos desde la armonía moderna. Música, Cultura y Pensamiento, 1(1), 131-138. Ibagué: Conservatorio del Tolima.

Sánchez Suárez, S. (2010). Bunde tolimense: ¿ritmo o mito? Música, Cultura y Pensamiento, 2(2), 99112. Ibagué: Conservatorio del Tolima.

Ramírez, A. C. (2010). Debussy: otro camino al atonalismo. Música, Cultura y Pensamiento, 2(2), 113-123. Ibagué: Conservatorio del Tolima.

Tovar Torres, H. G. (2011). Condición física de ingresantes a programas de música del Conservatorio del Tolima. Música, Cultura y Pensamiento, 3(3), 101-113. Ibagué: Conservatorio del Tolima.

Guarín Ramírez, N. (2011). Evaluación y rediseño de la Licenciatura en Música de la Facultad de Artes del Conservatorio del Tolima. Música, Cultura y Pensamiento, 3(3), 115-131. Ibagué: Conservatorio del Tolima.

Niño Castro, G. A. Concierto para Guitarra y Orquesta de Cuerdas del compositor Álvaro Ramírez Sierra. Música, Cultura y Pensamiento, 3(3), 133-159. Ibagué: Conservatorio del Tolima.

Boada Valencia, E. V. (2012). Los bambucos de los nacionalistas colombianos: de Pedro Morales Pino y Emilio Murillo Chapul a Leonor Buenaventura de Valencia. Música, Cultura y Pensamiento, 4(4), 69-88. Ibagué: Conservatorio del Tolima.

Ramírez, A. C. (2012). El enfoque armónico durante el Romanticismo europeo: enriquecimiento de los medios existentes. Música, Cultura y Pensamiento, 4(4), 89-100. Ibagué: Conservatorio del Tolima. 
Ospina Romero, S. (2013). La obra musical de Luis Antonio Calvo. Música, Cultura y Pensamiento, 5(5), 121-154. Ibagué: Conservatorio del Tolima.

Ávila Roa, J. A. (2013). Relación entre la actitud postural y el desempeño frente al piano a partir de la Técnica Alexander. Música, Cultura y Pensamiento, 5(5), 155-175. Ibagué: Conservatorio del Tolima.

\section{Informes de Investigación}

Hernández Guayara, A. (2010). Análisis bibliométrico de los Trabajos de Grado de la Licenciatura en Música del Conservatorio del Tolima (20082010). Música, Cultura y Pensamiento, 2(2), 127-139. Ibagué: Conservatorio del Tolima.

\section{Separata}

Alarcón, J. G. (2009). Fantasía sobre Juan el Bautistapara órgano. Música, Cultura y Pensamiento, 1(1), 1-20 [Separata]. Ibagué: Conservatorio del Tolima.

Ramírez, A. C. (2010). Nocturno Op. 20 para orquesta de cuerdas y oboe. Música, Cultura y Pensamiento, 2(2), 1-12 [separata]. Ibagué: Conservatorio del Tolima.
Niño Castro, G. A. Concierto para Guitarra y Orquesta de Cuerdas del compositor Álvaro Ramírez Sierra. Música, Cultura y Pensamiento, 3(3), 133-159. Ibagué: Conservatorio del Tolima.

Luna Buenaventura, J. P. (2012). Tres obras para piano de Óscar Buenaventura. Música, Cultura y Pensamiento, 4(4), 1-20 [separata]. Ibagué: Conservatorio del Tolima.

Vivas Barrera, M. C. (2013). Colcorpia: Para tres voces, percusión y computador con tratamiento sonoro en tiempo real. Música, Cultura y Pensamiento, 5(5), 1-20 [separata]. Ibagué: Conservatorio del Tolima.

\section{Reseñas}

Niño Castro, G. A. (2013). Perilla, J. (Ed.), “La Guitarra clásica en la Radio Nacional de Colombia 1968-1978" (CD). Música, Cultura y Pensamiento, 5(5), 179-181. Ibagué: Conservatorio del Tolima.

Galindo Palma, H. (2013). Cuartas Coymat, Á. y Caro Greiffenstein (trad.), "El Conde de Gabriac en Ibagué”. Música, Cultura y Pensamiento, 5(5), 183-185. Ibagué: Conservatorio del Tolima. 


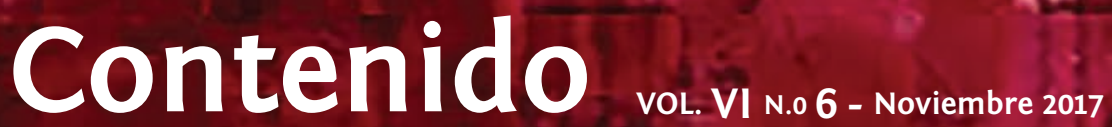

\author{
4 \\ 5 Editorial \\ Música y Cultura \\ Índices Revista Música, Cultura y \\ Pensamiento \\ Humberto Galindo Palma \\ 52 Música en Clave \\ propuesta de reedición e interpretación \\ Cristhy Alejandra Hoyos López, \\ Julián David Quintero Guzmán
}

Convocatoria Revista N. ${ }^{\circ} 7$

\section{Música y Pensamiento}

46

El piano y la niña del conservatorio Jaques Dalcrozze,

Juliana Pérez González (traducción)

\section{4}

\section{Reseña}

Música y Arqueología en Colombia, en busca de audiencias

Humberto Galindo Palma

\section{Separata}

Delirio de Amor Op. 19

Eugenio Zamora García

Asobbio a Játo

Heitor Villa-Lobos 